\title{
DESCRIÇÃO PRAGMÁTICA DA ATUAÇÃO DO SUPREMO TRIBUNAL FEDERAL EM DIREITO A SAÚDE
}

\author{
"As linguagens estão no mundo e nós estamos na linguagem [...]. " \\ (SANTAELLA, 2006, p. 13).
}

Fernando Rister de Sousa Lima ${ }^{1}$

\section{Resumo}

A pesquisa analisa a jurisprudência do Supremo Tribunal Federal - STF no tema direito à saúde com o objetivo de descrever a racionalidade da suprema corte brasileira por meio da classificação dos argumentos utilizados nas decisões analisadas segundo a pragmática de autoria do filósofo linguista Charles Peirce. Para o levantamento empírico, por meio dos métodos de pesquisa, utilizou-se a investigação documental, coletada de precedentes judiciais do STF. Os resultados da investigação basicamente foram:

1. Uma proposta de classificação dos argumentos utilizados pelos acórdãos em três grupos: interpretante energético, interpretante emocional e interpretante lógico;

2. Uma nova leitura do processo decisional no STF.

Palavras-chave: Direito à saúde. Supremo Tribunal Federal. Pragmática. Argumentos. Interpretante.

\section{INTRODUÇÃO}

A observação das decisões judiciais desperta no observador uma curiosidade pelo caminho escolhido pelo aplicador da norma abstrata à norma individual. $\mathrm{O}$ interesse aumenta à medida que o resultado - o decisum ou a ratio - afasta-se do previamente delineado pela dogmática. Ademais, esse anseio apimenta-se consideravelmente se o observador for parte sucumbente na referida relação julgada.

$\mathrm{O}$ andamento processual pode ser visto como um quebra-cabeça. $\mathrm{O}$ magistrado realiza um processo de racionalidade com o encaixe mental dos fatos ofertados pelas partes no direito posto. Entretanto, a sua razão fundamental - responsável pela tomada de posições ideológicas dentro do processo - é ligada umbilicalmente ao seu sentir, num ato mesmo subjetivo. Tal racionalidade é intitulada, em regra, como convicção. Configura-se como sentimento íntimo, próximo da intuição, a qual o ordenamento jurídico obriga que seja demonstrada na

\footnotetext{
${ }^{1}$ Doutor em Filosofia do Direito e do Estado pela Pontifícia Universidade Católica de São Paulo (PUC/SP) com estágio doutoral sanduíche no Departamento de Sociologia da Università di Macerata (UNIMC), Itália. Professor titular do Centro Universitário Toledo (UniToledo), Araçatuba/SP. Segundo Vice-Presidente da Associação Brasileira de Pesquisadores em Sociologia do Direito (ABraSD).E-mail: fernando@zuleicarister.adv.br
} 
decisão com o nome de convicção racional. Com efeito, os argumentos verbalizados nas decisões acabam sendo um dos poucos materiais empíricos passíveis de ser objetivados em termos de uma classificação racional.

O direito é objeto natural por excelência sob o viés da semiótica jurídica. Ele constrói uma realidade autônoma com base em sua linguagem, porém, denota-se, por trás disso, todo um processo ético, moral e social que se vê refletido nos interpretantes, os quais, no caso da pesquisa, são as próprias decisões analisadas. Desta forma, fica claro que o direito regula, trabalha e representa relações sociais, com nítidas valorações, ou seja, existem valores escolhidos pelos intérpretes. Cria-se um signo extraído de outro.

Também no aspecto da semiótica ao partir da Constituição Federal, o Supremo Tribunal Federal ao julgar se depara com um signo com toda uma carga valorativa, a qual a Corte usará como ponto de partida, com o escopo de realizar uma semiose comunicativa, bem à moda de Peirce, num diálogo de fases do ego, mesmo porque o signo reclama ser traduzido; em razão disso a expressão não-ser de RotiTurin. Esse processo sempre está permeado por valores, algumas vezes facilmente identificáveis, outras não. A escolha pressupõe valores sociais, preferências, dos quais se extrairá uma realidade, vista neste trabalho como racionalidade ou razão de julgamento (ARAUJO, 2011, p. 7-9, 15; TURIN, 2007, p.47-52).

$\mathrm{O}$ artigo analisa a jurisprudência do STF em direito à saúde sob as lentes da pragmática peirceana. Materializa parte das conclusões ainda inéditas de uma pesquisa financiada pela CAPES na qual se pretendeu descrever a racionalidade da suprema corte brasileira por meio da classificação dos argumentos utilizados nas decisões analisadas segundo a filosofia da linguagem de Charles Peirce. Aqui, quase como uma fotografia, faz-se um corte ou, precisamente, um recorte: desconsidera-se momentaneamente o futuro e o passado. Objetiva-se uma extensão cognoscível - ou seja, determinados acórdãos do STF -, para classificá-la na perspectiva pragmática.

No que tange à metodologia, o trabalho foca-se na constatação de uma realidade já posta no direito positivo pelo STF. Portanto, extraída da observação e do recorte para demonstração da sua verbalização. A forma de aproximação do material observado é importante. Como o material a ser analisado é o vernáculo para o exame das palavras usadas num determinado contexto, o instrumento foi a semiótica jurídica sob a óptica da pragmática de Charles Peirce. É latente a pertinência do uso da teoria dos signos a fim de extrair sentido do manancial linguístico dos precedentes analisados, mesmo porque o seu propósito é justamente o estudo dos signos, o que só é possível de se realizar em pesquisa empírica, destarte a sua natureza fenomenológica (GURVITCH, 1948, p. 29). ${ }^{2}$

\footnotetext{
${ }^{2}$ Aqui, este autor descreve o ideário de Max Weber, em que se defendeu, para a realização de pesquisa causal, o uso da interpretação dos significados, porém, focada na compreensão subjetiva dos atores em análise. Ver, ainda, para o uso da Semiótica, no estudo dos fatos sociais, Araujo (2011, p. 93, 95) e Silveira (2007, p. 21, 26). Nesta última página, o filósofo semioticista fala das pretensões da Semiótica, das quais se depara exatamente com a análise de uma inteligência no exercício do pensar. Eis um trecho pontual: "[...]. compreender mesmo que de maneira totalmente hipotética, como procede uma inteligência em seu ato mesmo de pensar. vol.09, nº. 01, Rio de Janeiro, 2016.pp. 56-83 
As pesquisas empíricas podem trabalhar, entre outros, com dois métodos de leitura das decisões, a saber: quantitativo e qualitativo. No primeiro, por exemplo, usa-se a matemática como vetor central. Foram analisadas dez decisões: cinco num sentido e o restante disperso em novas posturas. Chega-se a um resultado com base no que a maioria decidiu e pronto: quantitativamente se encontrou uma resposta.

No segundo formato (qualitativo), não se levam em conta como premissa maior os números e, sim, o conteúdo, a qualidade do teor grafado nas decisões. Perde-se em uma visão macro, todavia, ganha-se em qualidade nas observações feitas com mais vagar. Cada abordagem tem a sua vantagem e a sua desvantagem: uma vê o que a outra não vê e vice-versa. Consciente disso, optou-se pela qualitativa, contudo sem reduzir a quantidade exageradamente a fim de não perder, mesmo que parcialmente, o olhar macro em detrimento absoluto do micro nem incorrer até mesmo num certo subjetivismo do observador (CRESWELL, 2010, p. 25-47, sobretudo, p. 26, $35,37-38,40)^{3}$

Dessa forma, neste trabalho, não se pretende debater teses jurídicas. Deixa-se de lado a viabilidade ou não da construção jurídico-legal para se concentrar na leitura pragmática do fenômeno analisado. Por isso mesmo, fecham-se momentaneamente os olhos à sustentação jurídica, sem, no entanto, deixar de atentar para a linguagem utilizada nos acórdãos. Muito pelo contrário. O vernáculo utilizado será a própria matéria-prima a ser observada pela lente desta pesquisa teórico-empírica (TREVES, 1996, p. 209-221; GURVITCH, 1948, p. 28-29). ${ }^{4}$

\section{PRAGMÁTICA JURÍDICA NO CONTEXTO DO PROCESSO JUDICIAL}

No dia a dia do fórum, o discurso jurídico volve-se com as mais inusitadas decisões. Algumas dessas decisões com exegese da legislação pouco compreensível; outras, quando a própria base legal do pleito é reconhecida pelo julgador, nega-se a sua aplicação, justificada num subjetivismo a beirar o abuso de autoridade. Ao observar o processo de subsunção da norma abstrata pelo Estado-juiz, conclui-se que a prática forense é repleta de decisões sobre o significado das palavras. Ao julgar, por exemplo, a validade de uma cláusula contratual, obrigatoriamente, precisar-se-á indagar ou entender automaticamente o que é um contrato.

Esse processo, que é feito no contexto pragmático, com a efetivação de um significado gradativamente chega até a semântica e vice-versa, de modo que se eternize o processo comunicativo. É, pois, um procedimento natural e quase que indivisível, cujo desenrolar estende-se desde a observação do discurso até as questões

Quanto, pois, melhor conseguir detalhar esse ato, melhor alcançará aquilo que pretende conhecer.”. Ver, ainda, Santaella (2006, p. 14): "[...] a Semiótica busca divisar e deslindar seu ser da linguagem, isto é, sua ação de signo. Tão-só e apenas. E isso já é muito.".

${ }^{3}$ Na Sociologia do Direito, a respeito de pesquisa qualitativa, ver: Treves (1996, p. 204-205, 207); Gurvitch (1948, p. 16-33, sobretudo, p. 12, 16).

${ }^{4}$ Na página 28, Gurvitch (1948) relata a proposta epistemológica de Max Weber em que se propõe como mister da Sociologia a compreensão interpretativa das condutas sociais. No contexto da semiótica, ver Silveira (2007, p. 29): "[...] Para Peirce, seu objeto será o que é ou se apresenta no mundo real, sem questionar quais as condições de possibilidade desse modo de ser.”. vol.09, no. 01, Rio de Janeiro, 2016.pp. 56-83 
fundamentais do cálculo lógico, com passagem à cognição, daí o limite à semântica (CASTRO JR, 2009, p. 35, $52)$.

Sem embargo desse infinito processo comunicacional, a partir do ingresso de ação, a lide reclamará ser solvida por meio da decisão judicial. As partes levam, via petição inicial, contestação etc., os seus valores a respeito da justiça aplicável ao caso concreto. Ou, dito por outra forma, uma parte, representada por seu advogado, coloca a sua visão sobre a subsunção dos fatos à norma, enquanto o outro litigante narra o seu olhar a respeito da aplicação da legislação à situação em comento. Denota-se, pelo contexto, que os valores antagônicos se contrapõem quando insurge a disputa entre os litigantes. Consequentemente, acaba sendo o escopo processual solver o duelo, mediante a escolha de um ou mais valores, ou mesmo da melhor hermenêutica. A decisão positivará uma escolha, a qual pode agradar ou não as partes (ARAUJO, 2005, p. 40).

Trata-se de uma tomada de postura frente a valores de justiça conflitantes ou exegeses diferentes de uma mesma situação concreta que originou a disputa. Para a escolha, contudo, o julgador realizará um processo cognitivo complexo no qual serão levados em consideração, em grande escala, valores, como é o exemplo do formato de atuação jurisdicional, ligado umbilicalmente ao conceito e à extensão do princípio da separação de poderes. Tais decisões verbalizam unidades elementares conhecidas como normas jurídicas, resultado de um processo hermenêutico que opera utilizando o material já anteriormente positivado, como num círculo, em cuja última análise se materializa um ordenamento dinâmico. Por este sentido, o direito se produz via decisão (ARAUJO, 2011, p. 33).

Dentro dessa plêiade relacional, pode-se delinear uma relação a se iniciar com o suporte fático; melhor, a partir dele, do contato da mente do intérprete com o suporte fático tem início a semiose. Com este contato, a mente gera um segundo elemento, intitulado de signo. No caminho entre o contato da mente até a emissão do signo, tem-se, nessa linha, um ato de percepção propriamente. No cenário jurídico, por sua vez, esse processo é apimentado com as aspirações das partes, externadas em suas peças processuais, e com os aspectos culturais que influenciam demasiadamente os intérpretes nesse sistema de alinhamento do signo ao objeto. Consoante descrição de Peirce, isso ocorre na forma de um diálogo localizado, sob esse cerne, no pensamento do intérprete, de tal sorte que, com o uso da inteligência, sempre se está aberto à nova alimentação, mediante leis, fatos ou quaisquer outros signos, configurando-se como uma evolução semiótica (ARAUJO, 2011, p. 130, 132, 135, 136, 138-139, 144-146).

\section{PRAGMÁTICA JURÍDICA COMO METODOLOGIA}

Clarice von Oertzen de Araujo trouxe ao cenário jurídico estudo crítico sobre o fenômeno da incidência jurídica como tese de livre-docência defendida no Departamento de Teoria e Filosofia do Direito da 
Universidade de São Paulo. Dentro da sua abordagem, entre outros temas, interessa a pesquisa o debate em torno do signo, do qual se abstrai que ele sempre representa um significado. Da leitura do signo, surge um significado para o intérprete.

Desta feita, as normas jurídicas também são símbolos, em cujo significado se regem as relações sociais, mas, no entanto, a sua significação não se exaure na interpretação do intérprete. Ao contrário disso, a interpretação das referidas normas trata-se de processo incompleto, que se depara com a continuidade do processo comunicacional pelo próprio interpretante ou pelos próximos, quando for o caso.

A interpretação jurídica pode configurar-se como um processo sempre em andamento. Daí que, ao enredo da pesquisa, identificar a simbologia em torno da separação dos poderes consiste em diagnosticar dentro da relação comunicacional dos ministros da Suprema Corte qual o sentido outorgado ao citado princípio, na concretude do direito à saúde. Por esse cenário, o STF pode ser descrito, ao menos sob o julgo da semiose comunicacional da pragmática jurídica, como mente coletiva do sistema jurídico (ARAUJO, 2011, p. 17-19, 21).

A legislação é descrita, dentro do manancial teórico da semiótica, como um material simbólico, haja vista que o seu texto tem o nítido escopo de representação. Tudo porque, quando o receptor da norma adquire contato com o seu conteúdo, cria-se na sua mente um significado. Em consequência, o mesmo signo é capaz de dar subsídio às mais diversas interpretações. Ademais, no caminho da norma geral e abstrata para a concreta, que consiste no produto final de um processo complexo, utiliza-se nova nomenclatura: se lá, inicialmente, falava-se em signo, com o mencionado processo, doravante, faz-se referência a índice.

Nesta pesquisa, na linha exposta no parágrafo anterior, observa-se a concretude da norma geral abstrata à norma concreta, dentro da jurisdicização dos fatos no âmbito do STF, com a consciência de que a apuração valorativa extraída somente tem validade dentro do direito, em razão de que o plexo comunicacional de cada sistema é muito específico, delimitado, e só possível de exegese dentro do respectivo contexto, mesmo sendo um fato social, uma vez que se trata de relações intersubjetivas resultadas nas decisões monocráticas e nos acórdãos analisados (ARAUJO, 2011, p. 29, 32, 34, 93).

O processo comunicacional de aplicação da norma ao caso concreto, dirimindo, com a decisão, o litígio - ao menos reduzindo naquele momento a complexidade processual ao pôr fim àquela fase processual e em alguns casos à própria disputa - produz uma semiose; daí se extrai que o significado dessa ação e reação é um resultado interpretativo a redundar na continuidade do ordenamento jurídico. Este resultado, que apenas num determinado momento é tido como produto final, propriamente como o objeto em observação desta pesquisa, tem sim uma causa possível de ser cognoscível no seu processo decisório. Entretanto, não se trata de processo rigidamente causal, movido por leis rígidas, quase que naturais, mas sim formado por diversas variáveis, dentre as quais se destaca o axioma ideológico motivador do intérprete (ARAUJO, 2011, p. 122, 126). 


\section{SEMIOSE COMUNICACIONAL NOS PRECEDENTES ANALISADOS}

Sob o julgo da semiótica, com ênfase em Peirce, vislumbra-se na ação um dos pontos nevrálgicos da observação dos fenômenos sociais. Estudar o direito com tal consciência proporciona à pesquisa um olhar do significado social, em cujo conteúdo a tese alicerça-se. Ação produz significação social (ARAUJO, 2011, p. 43, $65)^{5}$

Então, com base na premissa de que toda ação gera um significado social, a pesquisa parte do pressuposto de que as atuações jurisdicionais do STF, materializadas nos acórdãos perquiridos, têm um significado social. E, ao trabalho, tal semântica interessa quando esbarra no princípio da separação de poderes. Dessa forma, o julgamento final, a tomada de decisão propriamente dita, passa por todo um procedimento intelectivo anterior, no qual cada passo sinaliza gradativamente o caminho a ser escolhido dentro das opções possíveis numa semiose comunicacional. ${ }^{6}$ Apesar disso, quando o ato resulta num produto final - a decisão -, a linguagem utilizada adquire significação própria, conforme a sua valoração no seio social.

À luz da semiose peirceana, o processo decisório judicial centra-se na interpretação conferida pelo intérprete ao ato, a qual é guiada por componentes culturais e sociais ligados ao momento histórico em que esteja inserido e sua carga psíquica adquirida pelos anos de formação acadêmica e familiar, pela convivência social, bem como, ou talvez, mormente, pela eventual base teórico-filosófica que o influencie, seja implícita, seja explicitamente (ARAUJO, 2011, p. 21-23, 34).

Esse valor social outorgado ao ato tem relativa conotação subjetiva pelo intérprete. Isso porque os axiomas fomentadores da sua realização são oriundos de um conjunto de fatores, como alguns dos citados no parágrafo anterior. Não obstante essa cética constatação, o processo de racionalidade jurídica, historicamente estudado, não é estático. Ao contrário, é dinâmico, forjado por valores sociais, culturais e econômicos, a resultar numa base axiomática, no caso, dos ministros do STF.7 Trata-se de uma exegese infinita, em constante realimentação. É verdade, por outro lado, que é possível fotocopiar essa racionalidade, tornando-a estática, analisada, interpretada e descrita num momento estático, como nesta pesquisa.

\footnotetext{
5 "Essencialmente mediado por signos, conclui-se que todo pensamento é de natureza interpretativa. Sequer o auto-conhecimento ou a consistência de si far-se-ão no imediato da intuição.” (SILVEIRA, 2001, p. 203).

6 "Para Peirce, em todos os momentos de sua obra, o conhecimento deve ser considerado semiose, e todo pensamento a que nos é possível ter acesso, compartilha dessa mesma natureza." (SILVEIRA, 2001, p. 204): "A potencialidade inerente à semiose, assim como a ausência de qualquer imediatez naquele processo, reforça a necessidade de interpretação da própria personalidade. Nada é representado que não exija a referência à experiência, nem que essa seja a de nós mesmos. De nós mesmos, portanto, exige-se um trabalho mediado de signos e um tempo para que desenvolvam os interpretantes." (SILVEIRA, 2001, p. 203).

7 "[...] A experiência do pensar é uma experiência do contínuo, antes mesmo que qualquer análise identifique a natureza dessa temporalidade. Assim também, mesmo que se possa vir a poder medir-se ou comparar-se qualidades, inclusive a que se responsabiliza pela semiose, essa última permanecerá sendo um contínuo, cujo fluir jamais se reduzirá aos limites de uma representação conceptual, necessariamente abstrativa." (SILVEIRA, 2001, p. 208).
} 
A semiótica busca no método indutivo - parte do particular para o geral - um instrumental de pesquisa para descrever as formas ideais dos signos investigados, os quais só são passíveis de interpretação se coletados na sua forma empírica. Nos acórdãos, o material empírico da pesquisa se identifica com uma inteligência científica que sempre está reaprendendo por meio da experiência (SILVEIRA, 2007, p. 21). ${ }^{8}$

Demais que, sob o julgo do instrumental semiótico peirceano, o processo de formação do signo é dividido, melhor, analisado com enfoque em três elementos: signo ou representamen (sempre representa algo a alguém); interpretante (ideia sob o signo a ser transmitida do objeto); objeto (do signo). A esse processo comunicacional de formação do signo, cunhado obrigatoriamente pelos três referidos elementos, de forma incessante, ininterrupta e constante, dá-se o nome de semiose, conforme se exemplifica na Figura 1, seguinte (SILVEIRA, 2007, p. 30-31, 34-35). ${ }^{9}$

Figura 1 - Semiose peirceana

\section{INTERPRETANTE}

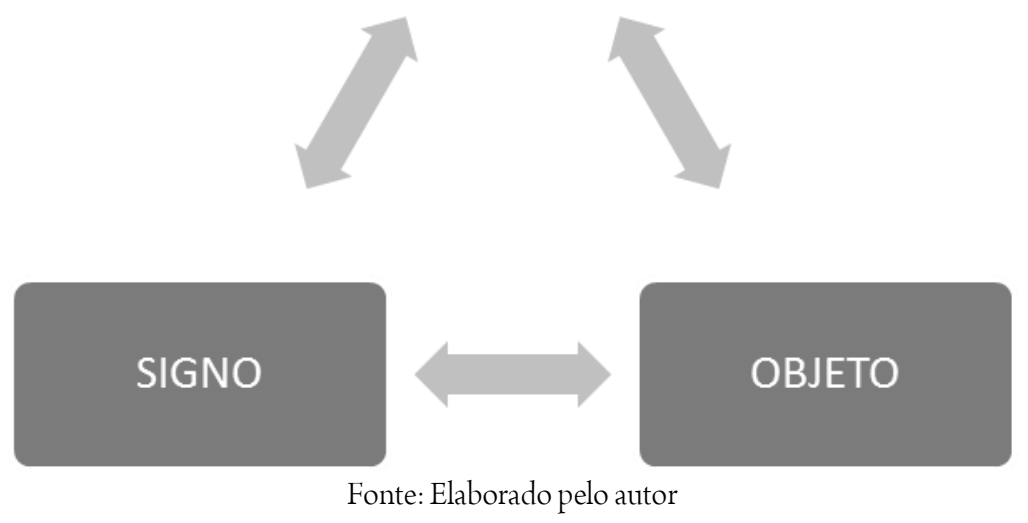

Por meio da pesquisa, talha-se uma abordagem estática, de instrumental semiótico, que tem a pragmática como metodologia, com o mote de chegar à semântica, com a ressalva de serem partes de um mesmo processo, cujo resultado analítico pode caracterizar-se com as seguintes proposições.

\footnotetext{
8 "A Semiótica é uma ciência rigorosa, construtora de formas ideais, pelas quais por via dedutiva e, portanto, a modo de necessidade, demonstrará suas conclusões. [...]. Com efeito, seu objeto - os signos - pertence ao universo fenomênico e só alcançado em suas manifestações empíricas. É necessário observá-lo onde quer que se manifeste e tal manifestação, distinguindo-se da pura produção da razão, dela independe, esconde-se e dissimula-se. Jamais, pois, a Lógica terá totalmente exposto a sua explicação, mas precisará buscá-lo no universo da experiência e construir sobre ele hipóteses que o expliquem." (SILVEIRA, 2001, p. 204, 212).

9 "[...] O Objeto de um signo é uma coisa: seu significado, outra. Seu objeto é a coisa ou a ocasião, ainda que indefinida, à qual ele deve aplicar-se: Seu significado é a idéia que ele atribui àquele objeto, quer através de mera suposição, ou como uma ordem, ou como asserção." (PEIRCE, 1999, p. 194).
} 
1. A semiose comunicacional é um processo infinito, ininterrupto, exatamente por isso contingente, em que o interpretante ocupa papel de destaque. Por essa assertiva, os conceitos não são estáticos, mas, sim, dinâmicos, artificiais, a depender de novos processos hermenêuticos em cujo resultado assentará os seus novos lineamentos. Para ir além, esses conceitos são capazes, dentro da semiose, de se transformar, adaptar-se.

2. A pragmática alimenta a semântica e vice-versa. Tem-se um processo comunicativo em que os utentes conotam novos signos, a desembocar numa nova semântica. Descreve-se uma semiose em sintonia com a epistemologia de Peirce.

3. Existe sim, dentro da base de dados extraída nesta perquirição, uma racionalidade definida em relação ao princípio da separação dos poderes, propriamente numa semântica.

4. À luz da semiótica, o ordenamento jurídico é vivo. Pode, sim, ser observado de maneira estática, contudo, está sempre em movimento. Sua semiose é infinita. A única certeza é que novas comunicações estão se formando. Seu jogo comunicativo está sempre atuando. Exatamente por isso, o direito positivo positiva-se via linguagem. As verbalizações extraídas das decisões analisadas identificam o sentido outorgado dentro do contexto cultural atual.

5. Desse processo comunicacional, outrossim, infere-se que o certo e o errado estão num constante duelo, o que leva à dura conclusão de que as verdades, as premissas, os axiomas jurisdicionais são momentâneos. Nisso, inclui-se o princípio da separação dos poderes. O clássico sentido liberal não é mais usado; ficou para trás, dentro da semiose da Suprema Corte. Trata-se de um processo, gradual, no qual novas verbalizações vão surgindo para, paulatinamente, antigas semânticas conceituais serem substituídas, sem exclusão do processo inverso também acontecer.

6. A análise da pesquisa empírica não deixa dúvidas sobre a constatação de Peirce de que o signo não esgota os vários aspectos do objeto que representa. As múltiplas, e complexas, perspectivas de observação surgidas ao longo da pesquisa só ratificam o ideário peirceano. Não é possível uma conclusão final e segura sobre questões abertas. Cada lente resultará em signos distintos.

7. Um signo sempre substitui significativamente algo. Nesse sentido, o significado do signo é sempre outro signo. No contexto da pesquisa, a petição que leva ao STF o pleito da parte é um signo, que travará com as normas constitucionais uma relação de significação. Contudo, com a contestação da peça, mesmo como reação à primeira, forma-se uma relação em nível de secundidade.

8. Dentro dessa semiose, a Suprema Corte é a "mente coletiva" que trava com as duas peças processuais comentadas - petição e contestação - uma relação de terceiridade, numa generalização, de modo que o acórdão é o interpretante, que, visto pelo processo estático, pode ser rotulado de interpretante final. 
9. Os acórdãos analisados podem ser, ainda, chamados de signo-resultado. São signos na medida em que formam um signo em cima de outro signo, como resultado do processo comunicacional iniciado possivelmente pela interposição de um recurso extraordinário, tido aqui como signo, vez que porta o significado da parte para o pleito, numa perspectiva do possível e da análise sintática. Com a apresentação das contrarrazões pela recorrida, instaura-se outra semiose a fim de que sejam levados em consideração os argumentos da outra parte. Uma dialogia entendida como um diálogo entre os argumentos apresentados no recurso e os ofertados pela recorrida, a serem enfrentados na decisão do STF.

No material coletado, nas decisões da Suprema Corte, sob o viés semiótico, depara-se com a semiose comunicacional do princípio da separação dos poderes em sintonia com o descrito por Charles Sander Peirce que pensou a semiótica como ciência lógica da lógica da experiência, tendo como consequência a identificação da vagueza como estrutura propícia a demonstrar com nitidez a intersubjetividade do processo comunicacional. Neste cenário, comenta-se que os princípios jurídicos se materializam em construções gramaticais vagas. Dentro da dogmática, inclusive já se propôs diferenciar os princípios das regras justamente por essa "abertura", enquanto as regras seriam normas mais rígidas com pouca, ou nenhuma, abertura interpretativa (NEVES, 2013, p. 12-26), não sendo diferente com o princípio da separação dos poderes.

Com efeito, o trabalho também se deparou com a vagueza do texto constitucional a propiciar a comunicação que, à proporção que se debatem nos julgamentos no STF a extensão e os limites da atuação jurisdicional na concretude do direito à saúde os valores vem à tona, consoante se expôs no próximo item, em que se identificou argumentos das decisões em níveis de primeiridade, secundidade e terceiridade comunicacional. Esse debate de sentido em torno da separação dos poderes, ou mesmo do direito à saúde, fez com a comunicação saísse do plano abstrativo para, por meio de escolhas concretas dos envolvidos, outorgar concretude do pensamento mediante ação.

\section{RESULTADO: UMA PROPOSTA DE SISTEMATIZAÇÃO DO MATERIAL EMPÍRICO PELAS CATEGORIAS PEIRCEANAS}

A semiótica concebida por Peirce como procedimento científico descreverá o fenômeno observado por meio de um diagrama, que se materializará numa figura, com intento de identificar o fenômeno observado e pensá-lo avante. Pensa-se no futuro, depois de descrever o real. Usa-se a expressão: "deve ser" para identificar essa projeção do futuro com base na sequência lógica do raciocínio do signo observado, sem embargo da consciência da falibilidade dessa prospecção do porvir. Forja-se uma regularidade falível. Para isso mesmo, faz-se necessário o detalhamento voltado à compreensão dos passos que a inteligência deu para formar o signo observado, 
identificado no caso desta pesquisa nos diagramas a seguir expostos (SILVEIRA, 2007, p. 23, 25-26, 28, 38; PIERCE, 1999, p. 199). ${ }^{10}$

No arauto de compreender os passos que a inteligência segue para formar o signo, é preciso considerar os componentes básicos desse processo de visualização fenomênica, denominado de categorias, grafadas como:

1. primeiridade;

2. Secundidade;

3. Terceiridade.

Organiza-se, ou melhor, auto-organiza-se a realidade por meio do pensamento. As categorias são, nesse sentido, o pensar da própria realidade projetada pela mente. Com isso, representam-se desde os sentimentos mais simplórios até os mais elevados processos evolutivos (SILVEIRA, 2007, p. 38-43; SANTAELLA, 2002, p. 143).

$\mathrm{Na}$ primeira categoria, aponta-se o sentimento originário; um sentimento bruto, livre, precisamente como a imagem imediata do presente. A realidade é começada por ela. Por isso mesmo, a primeiridade é representada no diagrama por um ponto ligado a um traço (SILVEIRA, 2007, p. 41-42). Na segunda, a secundidade, trata-se de ação e reação. Há uma situação e sua contestação já é materializada como o passado. Tem dinamismo. Flui de uma relação com o outro. É formada por dois elementos, sendo um deles a própria primeiridade. Cunha-se a partir dela (primeiridade) um ato de confronto com outro elemento. No gráfico, é apontada como dois pontos unidos por traços (SILVEIRA, 2007, p. 41-42).

Por fim, a terceiridade é propriamente um salto, uma tentativa de prever o futuro por meio da artificialidade da mente. Parte-se da lógica do raciocínio até então travado para dar um passo adiante com uma previsão falível do amanhã. É a forma da evolução do pensamento. Gera um interpretante. A mente está na terceiridade. Não há uma mecanicidade desse raciocínio, ao contrário, há um salto no raciocínio. Sem ele não há evolução. Está em relação simultânea com o segundo. É identificada graficamente com dois pontos dotados de traços (SILVEIRA, 2007, p. 41-42).

Submerso no cenário das categorias, o direito positivo é mais propenso à terceiridade. Contudo, no cenário comunicacional da pesquisa, a petição recursal, ou equivalente, que venha a portar o litígio à Corte, acaba que significando a materialização do problema a ser volvido judicialmente. Por si só, o recurso interposto constrói um símbolo, que neste caso remonta ao próprio sentimento primeiro da parte, puro, numa perspectiva sintática de

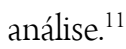

\footnotetext{
10 "A forma do signo contribui para sua inteligibilidade e facilita mais ou menos a interpretação e a fluir no pensamento. Nesse sentido, compreende-se a razão do grande empenho peirceano em construir e em constantemente aprimorar o sistema de grafos, ao qual reconhecia como uma de suas maiores contribuições à lógica e ao pensamento humano." (SILVEIRA, 2001, p. 207).

11 "Thomas S. Knight, interpretando epistemologicamente as categorias peirceanas, entende que a primeiridade, referindo-se a um sentido de qualidade ou a uma idéia de sentimento, seria um estado de consciência sobre o qual pouco pode ser afirmado, a não ser em termos negativos: é incomparável, não-relacional, indiferenciado, impermutável, inalisável, inexplicável, indescritível, não vol.09, nº. 01, Rio de Janeiro, 2016. pp. 56-83 
De outra forma, a intervenção da outra parte, regra geral, com a apresentação de sua contrarrazão ao recurso extraordinário, provoca um choque comunicacional, a surgir na tríade o signo (acórdão/julgamento), formada a partir do confronto das duas petições iniciais. O confronto processual das partes processuais provoca um símbolo que obrigatoriamente representa a petição inicial do recorrente e a defesa da recorrida. Trava-se uma relação em nível de secundidade, como um novo símbolo, uma semântica oriunda do fruto do litígio de dois lados. Atenção: essa nova semântica se apresenta não como soma, mas, sim, como novo símbolo. Chocam-se ambos e o resultado insurge sob a máscara de um novo símbolo, todavia, rotulado como objeto. ${ }^{12}$

Com isso, o processo comunicacional, denominado por Peirce de semiose, está quase todo descrito e identificado no cotejo da pesquisa. Falta, nesse jaez, identificar o papel do interpretante, responsável pelo símboloresultado dentro desse processo, que na pesquisa é o próprio acórdão da Suprema Corte. A decisão acaba a interpretar o signo e o objeto, de tal sorte que, levando-se em conta os referidos signos, produza um terceiro signo, também chamado de supersigno.

No caso do material coletado, a peça recursal leva o sentimento primeiro à relação, a qual se chocará com a peça do ente estatal demandado, formando a secundidade. Contudo, ambos os símbolos serão interpretados pelo interpretante, o acórdão. Ele forma o símbolo final dentro dessa relação. Final, da perspectiva da análise, porque por outro prisma o processo ainda pode continuar a operar, valendo relembrar que a semiose comunicacional é infinita (PIGNATARI, 2004). ${ }^{13}$

Desse ponto de vista, com a pesquisa empírica, fulgura-se que as peças recursais do cidadão identificam, entre outros, o princípio da separação dos poderes como símbolo de cooperação, complemento, entre os poderes na atuação estatal, no caso da efetivação do direito à saúde. Ou seja, não foi ofertado pelo administrador público determinado remédio e as razões do recurso procuraram simbolizar que é possível a prestação do remédio por meio do Judiciário. De outro modo, as peças do Poder Executivo procuram formar um símbolo sobre a mencionada separação ligada à rigidez, com ânimo de vedar a intervenção do Estado-juiz em questões ligadas às funções dos outros poderes.

intelectual e irracional. Tratando-se de consciência instantânea, é não-cognitivo, original, espontâneo, é um simples sentido de qualidade - o sentido de qualidade de uma cor, por exemplo. [...]." (PIGNATARI, 2004, p. 44).

12 "[...]. Já a secundidade é uma idéia de fato, de luta, de resistência, de poder, de volição, de esforço. Realiza-se ou é percebida nos estados de 'choque', surpresa, ação e percepção. Metafisicamente, caracteriza-se pela alteridade, pelo não-ego. $\mathrm{O}$ aqui-e-agora de uma qualidade constitui uma secundidade." (PIGNATARI, 2004, p. 44).

13 “[...] Peirce cria um terceiro vértice, chamado Interpretante, que é o signo de um signo, ou, como tentei definir em outra oportunidade, um supersigno, cujo Objeto não é o mesmo do signo primeiro, pois que engloba não somente Objeto e Signo, como a ele próprio, num contínuo jogo de espelhos [...]. " (PIGNATARI, 2004, p. 49). "105. Terceiridade é para mim apenas um sinônimo de Representação; prefiro-o porque suas sugestões são menos estreitas. [...]." (PEIRCE, 1974, p. 39). "339. A idéia mais simples de Terceiridade datada de interesse filosófico é a idéia de um signo, ou representação. Um signo 'representa' algo para a idéia que provoca ou modifica. [...]." (PEIRCE, 1974, p. 37). 
Posto isso, tem-se, então, formado uma relação comunicacional em que a primeiridade e a secundidade estão caracterizadas. Enquanto, lá, há um sentimento puro, uma primeira impressão do assunto, aqui, com base no primeiro símbolo indicado pelo recorrente, em confronto com a reação trazida pela peça da recorrida, surge do conflito o objeto, que não é o símbolo final. Trata-se da configuração (identificação) do litígio propriamente dito.

Como decorrência lógica desse processo, a terceiridade é tipificada no exato momento em que o acórdão interpreta os símbolos constantes na primeiridade e na secundidade, a fim de produzir um símbolo-final, identificado na própria decisão final, a respeito da separação dos poderes, no que tange ao fornecimento de medicamentos mediante decisões judiciais. A partir daí, fala-se em um supersigno, oriundo desse processo semiótico triádico, num caráter de lei, cujo significado gerará um processo de generalização a partir dele, dando fomento a novos processos comunicacionais. Eis a configuração da terceiridade.

A relação triádica, no cotejo da semiose peirceana, pode ser visualizada na Figura 2, seguinte:

Figura 2 - Aplicação da tríade de Peirce

Decisão do STF

(INTERPRETANTE)

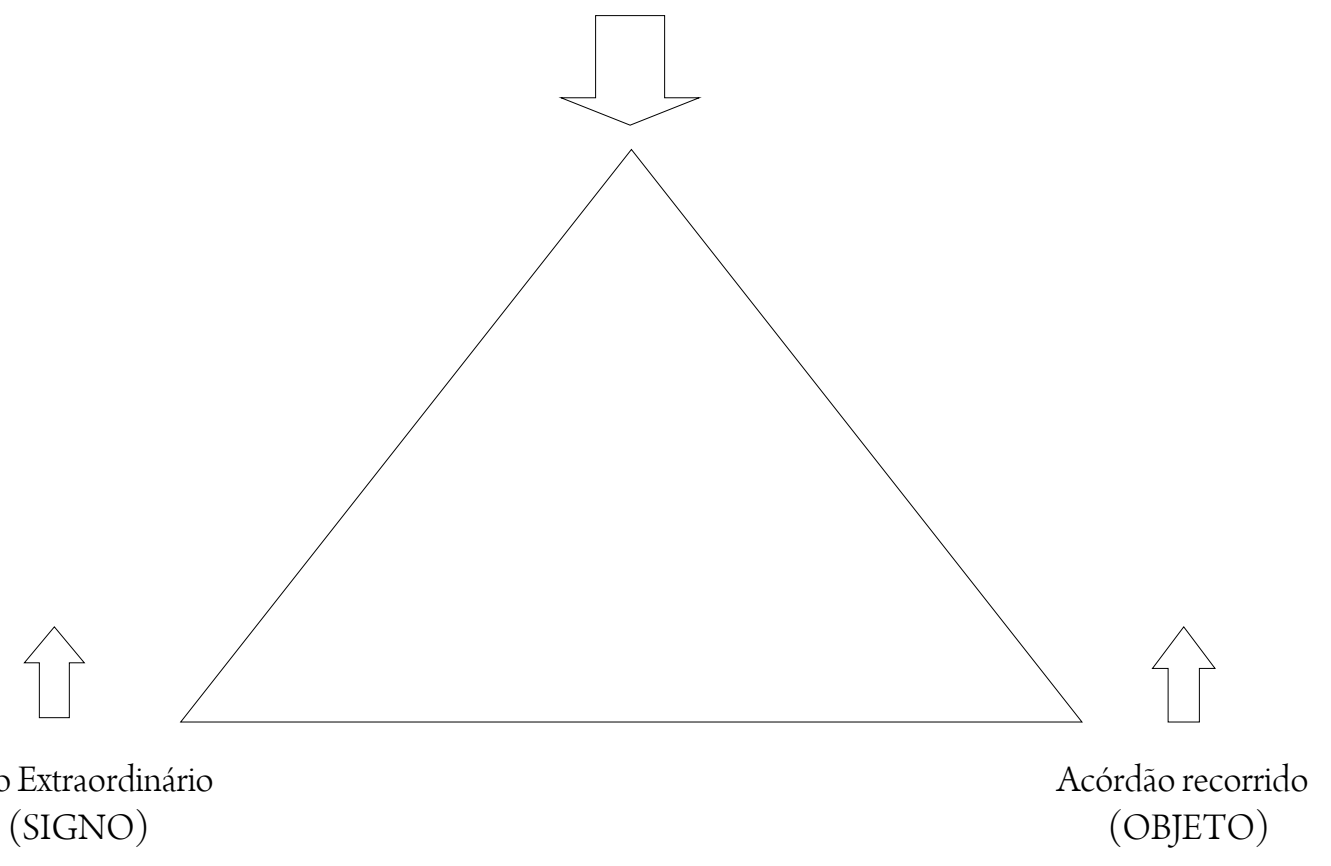

Fonte: Elaborado pelo autor

O produto final dessa semiose torna-se, na acepção do termo, um símbolo genuíno porque resultado da semiose triádica. Sem embargo, para ser mais bem compreendido, o interpretante reclama ser observado no contexto de toda a semiose. O seu teor simbólico deve ser visto em sintonia com o símbolo primeiro (peça 
recursal), objeto (acórdão recorrido). Daí ser possível compreender que o acórdão é a materialização física da ideia de signo oriundo dos argumentos usados pelos ministros.

Ainda, no caso da pesquisa, o próprio interpretante (o acórdão/STF) preocupa-se em descrever o signo e o objeto sob o rótulo de relatório, para, somente depois, no voto, promover a semiose, a resultar no símbolo final. Esse processo comunicacional, designado por Peirce de semiose, ocorre na forma de um diálogo, localizado, sob esse cerne, no pensamento dos ministros da Suprema Corte, com o uso da inteligência. Por vezes, esse diálogo é aberto à nova alimentação mediante leis, fatos ou quaisquer outros signos e, neste caso, configura-se como uma evolução, outras, a seu turno, não propenso a receber novas comunicações, pois fechado em si próprio. ${ }^{14}$

Por outra óptica do processo comunicacional poder-se-ia analisar a petição recursal (recurso extraordinário) como o interpretante de uma semiose, na qual o signo inicial seria a dialogia instaurada com o diálogo entre os argumentos trazidos à semiose pelo recurso de apelação e sua respectiva contrarrazão. Nesse diapasão, o objeto do signo seria o acórdão do tribunal a quo. Consequentemente, como interpretante do símbolo e do seu objeto, surgiria o recurso extraordinário como um novo símbolo, quando visto dessa lógica da cadeia comunicacional. ${ }^{15}$

Com a Figura 3, a seguir, demonstra-se a tríade: interpretante, signo, objeto.

\footnotetext{
${ }^{14}$ Para se compreender bem o processo triádico de comunicação aplicado ao STF, necessário se faz remontar à teoria da percepção peirceana, aqui explicada por Santaella (1998, p. 44-45): "Qualquer coisa que aparece à mente produz nela um efeito. Esse efeito é um primeiro em relação àquilo que aparece. Ao apreender aquilo que aparece, a mente imediatamente reage, produz algo. Esse algo é o segundo. Aí está: o signo, efeito, surge como primeiro e aquilo que provoca o signo, ou seja, seu objeto, como segundo. A primazia lógica é do signo, mas a primazia real é do objeto. O objeto é determinante, mas só nos aparece pela mediação do signo. [...]." No mesmo sentido SANTAELLA, 1995, p. 130, 132, 135-136, 138-139, 144-146. E Silveira (2001, p. 206) infere: "Mesmo, portanto, que o fluxo do pensamento se faça somente no interior de alguém, ele jamais será um monólogo. Não crescerá o pensamento e não alcançará sua meta e sua razão de ser, se quem o emite não se reconhecer incapaz de sozinho proceder à representação de um objeto e à equivalente determinação da conduta.".

15 "536. Já observei que um Signo tem um Objeto e um Interpretante, sendo o último aquilo que o Signo produz na Quase-Mente, que é o Intérprete, ao atribuir este mesmo último a um sentir, a um esforço ou a um Signo, atribuição esta que é o Interpretante." (PEIRCE, 1999, p. 177).
} 
Figura 3 - Materialização da tríade peirceana aplicada à pesquisa

Recurso Extraordinário

(INTERPRETANTE)

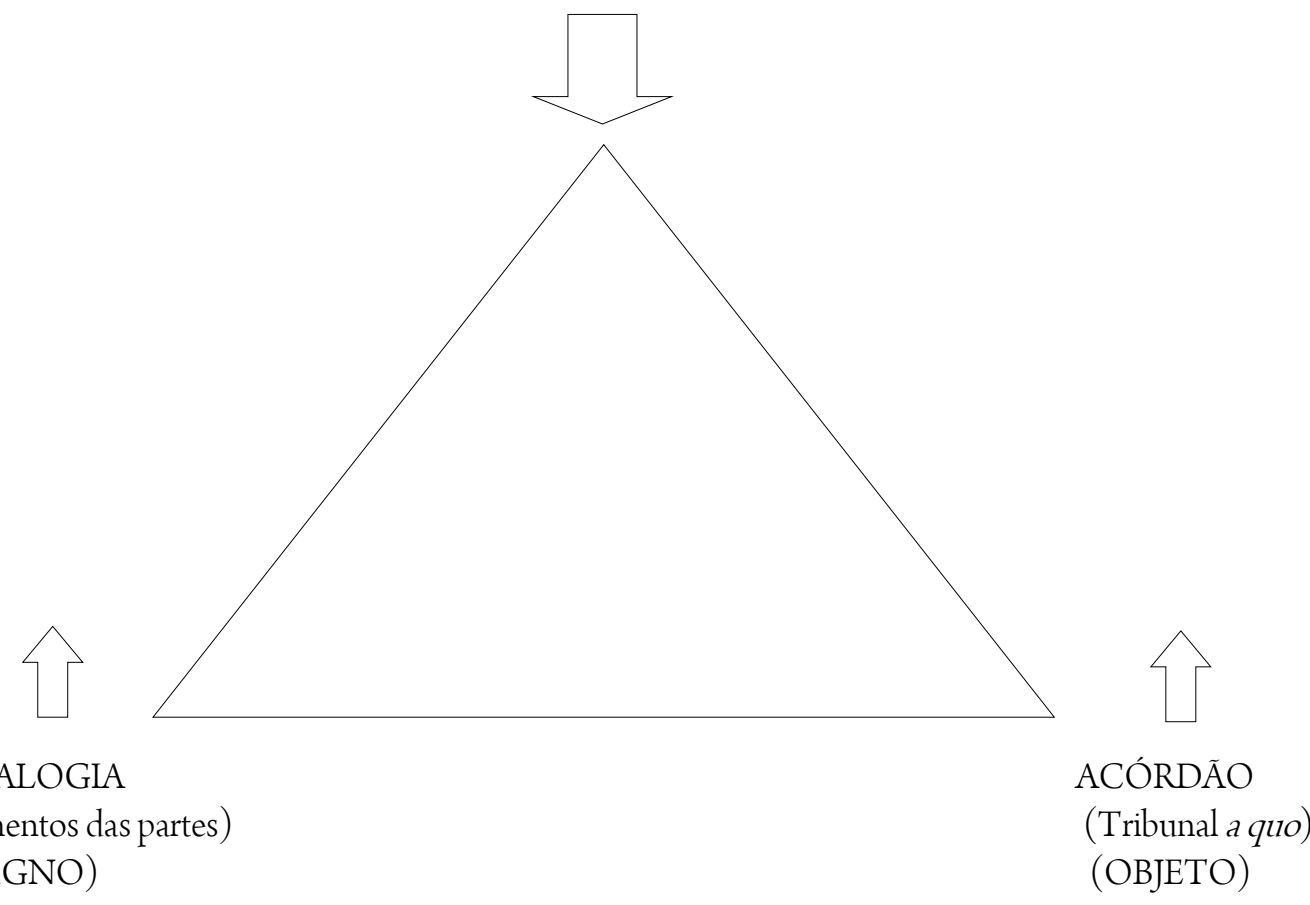

Fonte: Elaborado pelo autor

Como fecho, consigna-se que o STF, descrito pelas categorias, é predominante terceiridade, por uma soma de fatores, dos quais, frisa-se que as suas decisões governarão a relação das partes processuais de forma direta. De outro modo, de forma indireta, num formato generalizante, orientará a resolução de questões similares.

Não obstante o predomínio da terceiridade, a referida Corte, dentro da semiose, pode ser identificada em aspectos específicos como secundidade, porquanto a sua decisão representa, como um signo, os problemas sociais que motivaram a interposição dos recursos ao STF e assim sucessivamente ao signo primeiro identificado pela petição inicial proposta lá atrás, temporalmente falando. No caso especial da pesquisa, identifica-se uma significação para representar o litígio da saúde (visualizado por ação - o recorrente - e reação - o recorrido) como secundidade (SANTAELLA, 2002, p. 144)..$^{16}$

Lógico que para o objeto do trabalho, interessa mais o aspecto simbólico do material coletado, no qual, pelo estudo dos interpretantes, identificados pelas decisões da Corte, pode-se identificar o comportamento dos ministros, em ação concreta - leia-se nos julgamentos - como fenômeno vivo, mergulhado no cenário social histórico, econômico e cultural, de modo que, pelo símbolo, constata-se uma posição política quanto ao tema da saúde. Forma-se, nesse cenário, um signo-instituição (SANTAELLA, 2002, p. 148-149).

16 “[...] - signo é tudo aquilo o que substitui algo, sob certos aspectos e em certa medida-[...]"(PIGNATARI, 2004, p. 49). vol.09, no. 01, Rio de Janeiro, 2016. pp. 56-83 
Para formação, no entanto, desse signo-instituição, a semiose passa pela sua tríade que na terceiridade remonta à mente dos intérpretes, no caso da pesquisa, os ministros da Suprema Corte brasileira. Sob o julgo do pensamento, os ministros, internamente, primeiro debatem a questão para, depois, externarem o seu posicionamento aos demais membros da Corte.

Desse modo, a semiose tem uma perspectiva interna aos interpretantes, sendo iniciada pela percepção do signo. $\mathrm{O}$ resultado desse processo interno às mentes dos julgadores pode também ser rotulado de interpretante imediato, visto mesmo como um signo que produz no interpretante particular, no caso um dos ministros. Esse símbolo, que virá à tona como resultado da semiose particular de cada intérprete, é constituído por uma associação praticada pela mente do intérprete. Nesse cenário, Peirce classifica os interpretantes dinâmicos em três perspectivas:

1. Interpretante emocional;

2. Interpretante enérgico;

3. Interpretante lógico (SANTAELLA, 2002, p. 24-25). ${ }^{17}$

Os três estão ligados essencialmente às categorias peirceanas da primeiridade, secundidade e terceiridade.

Após a análise teórica e a sua aplicação à parte do material empírico coletado, explana-se que o interpretante emocional está no plano da primeiridade, na forma de um sentimento puro; uma qualidade oriunda de um primeiro efeito do contato com o signo. No caso em análise, a mente dos ministros acaba percebendo e expondo o signo como um fenômeno na sua pureza inicial, no formato de um sentimento. Noutro sentido, o interpretante energético atua no plano da secundidade porque se encontra como um resultado de ação e reação, a resultar a sua resposta com dispêndio de energia: uma produção do signo um pouco mais elaborada, do aspecto semiótico, identificada pela energia da sua comunicação, que deve estar apta a refutar sentidos contrários à sua interpretação. Enfim, a terceiridade é representada pelo interpretante lógico, o qual interpreta de forma mais elaborada, num viés interpretativo, sob premissas bem definidas por ele próprio.

Com destaque, é necessário grafar que, no contexto do processo comunicacional da semiose, as categorias são fases do idêntico processo. Analisa-se, assim, um estado do processo comunicacional. Ou seja, a terceiridade é uma fase do diálogo que contempla obrigatoriamente, antes dela, a secundidade e a primeiridade.

Peirce descreve o fenômeno como um círculo, transcrito abaixo para ilustrar a semiose. Nem por isso, deve-se deixar de analisar a parte específica do momento semiótico, com escopo de dar ênfase à terceiridade, por exemplo.

\footnotetext{
17 "Os signos são divisíveis conforme três dicotomias, a primeira, conforme o signo em si mesmo for uma mera qualidade, um existente concreto ou uma lei geral; a segunda, conforme a relação do signo para com seu objeto consistir no fato de o signo ter algum caráter em si mesmo, ou manter alguma relação existencial com esse objeto ou em sua relação com um interpretante; a terceira, conforme seu Interpretante representá-lo como um signo de possibilidade ou como um signo de fato ou como um signo de razão." (PEIRCE, 1999, p. 243).
} 
Dito dessa maneira, o importante é entender que a classificação a seguir proposta, dos $\underline{\text { argumentos }}$ utilizados pelos ministros paradigmas da Suprema Corte, como interpretantes emocionais, energéticos e lógicos, é tão só uma das possíveis faces da análise, torneada com base no que esta tese considera como primazia na atuação dos interpretantes analisados.

Consoante se direciona a óptica da análise da semiose, os atores mudam de papel, todavia, tudo dentro da rígida sistematização peirceana, a qual permite uma infinita linha de continuidade de produção de signos. Com esse espírito, aventa-se que, quando se parte dos acórdãos como interpretantes, os ministros são intérpretes que, com base num pensamento inicialmente individual, chegarão ao símbolo final, em regra, mediante diálogo com os outros ministros, para, juntos, formarem o interpretante, o supersigno, isto é, o acórdão no qual se consubstanciará o signo emitido do litígio proposto à Corte.

De outro modo, porém, ao se perquirir na dimensão de que cada voto é um interpretante, faz-se um novo recorte na análise para não mais investigar o acórdão pelo prisma do resultado final, como seria o normal vale comentar.

A partir dessa nova proposta de observação, tem-se a possibilidade de não mais classificar o acórdão, mas os argumentos utilizados pelos ministros, individualmente, nos termos do seguinte quadro.

Quadro 1 - Classificação dos argumentos dos ministros paradigmas em direito à saúde

\begin{tabular}{|c|c|c|}
\hline MINISTRO & DECISÕES PARADIGMAS & INTERPRETANTE \\
\hline Celso de Mello & $\begin{array}{l}\text { Ag. Reg. nos REs n. }-271.286-8 / \text { RS 273.834/RS e } \\
\text { 393.175-O/RS }\end{array}$ & Energético \\
\hline Marco Aurélio & $\begin{array}{c}\text { RE ns. } 247.900 / \text { RS e } 368.564 / D F \\
\text { Ag.Rg. no RE n. } 238.328\end{array}$ & Emocional \\
\hline $\begin{array}{l}\text { Gilmar } \\
\text { Mendes }\end{array}$ & $\begin{array}{l}\text { Ag.Reg. na Suspensão de Liminar n. 47/PE, na STA n. 175/CE e na SS } \\
\text { n. } 3355 / \mathrm{RN}\end{array}$ & Lógico \\
\hline
\end{tabular}

Fonte: Elaborado pelo autor

Sob a classificação proposta, assevera-se que não se trata de um julgamento a respeito do ministro, nem de sua atuação de modo geral. Ao contrário disso, mira-se exclusivamente nos argumentos utilizados nas decisões coletadas na tese, por isto mesmo, falíveis e restritos a uma visão parcial dos argumentos utilizados na atuação jurisdicional do ministro paradigma no que diz respeito ao direito à saúde. Dada essa necessária explanação, passase a explicar o porquê da classificação, nos moldes que seguem.

Pelo vernáculo utilizado retro, identifica-se que a secundidade é caracterizada essencialmente por um signo que representará a ação e a reação, ou seja, os argumentos favoráveis e contrários ao direito à saúde, no caso 
da tese, porém, já com uma tomada de posição, diga-se uma escolha efetivada com muita clareza. Nesse caso, o símbolo em desfavor é identificado como produto do choque comunicacional das posições contrárias, de modo a resultar numa postura como certa. Quando se expõe uma escolha como correta, conota-se nas suas palavras uma verbalização enérgica; evidencia-se a sua posição de forma a desqualificar a outra opção. Esse jogo com as palavras fica muito claro no trecho transcrito a seguir:

A INTERPRETAÇÃO DA NORMA PROGRAMÁTICA NÃO PODE TRANSFORMÁ-LA EM PROMESSA CONSTITUCIONAL INCONSEQÜENTE. [...] DISTRIBUIČÃO GRATUITA, ÀS PESSOAS CARENTES, DE MEDICAMENTOS ESSENCIAIS À PRESERVACCÃO DE SUA VIDA E/OU DE SUA SAÚDE: UM DEVER CONSTITUCIONAL QUE O ESTADO NÃO PODE DEIXAR DE CUMPRIR. - O reconhecimento judicial da validade jurídica de programas de distribuição gratuita de medicamentos a pessoas carentes dá efetividade a preceitos fundamentais da Constituição da República (arts. 5o, 'caput', e 196) e representa, na concreção do seu alcance, um gesto reverente e solidário de apreço à vida e à saúde das pessoas, especialmente daquelas que nada têm e nada possuem, a não ser a consciência de sua própria humanidade e de sua essencial dignidade. Precedentes do STF [Grifo nosso].18

Para pormenorizar a questão, comenta-se que quando o Ministro Celso de Mello grafa que a interpretação da norma constitucional não pode transformá-la em promessa inconsequente, posiciona-se como interpretante enérgico, em nível de secundidade, porque denota, no primeiro início, a síntese dos dois lados: direito à saúde com força vinculante e direito à saúde como norma programática. Portanto, acaba por produzir uma reação a essa dicotomia, bem como, de forma dura, implacável, coloca que a interpretação não pode tornar-se promessa inconsequente. Ressalta-se a expressão "inconsequente".

Produziu-se, à luz disso, uma interpretação enérgica, a qual é reforçada pelo trecho logo a seguir, também acima transcrito, ao utilizar as palavras:

E representa, na concreção do seu alcance, um gesto reverente e solidário de apreço à vida e à saúde das pessoas, especialmente daquelas que nada têm e nada possuem, a não ser a consciência de sua própria humanidade e de sua essencial dignidade" (BRASIL. Supremo Tribunal Federal. Agravo Regimental no Recurso Extraordinário n. 271.286-8/RS, j. 12.09.2000, grifo original” ${ }^{19}$

\footnotetext{
${ }^{18} \mathrm{O}$ trecho pode ser encontrado, entre outros acórdãos relatados pelo Ministro Celso de Mello, nas seguintes decisões: BRASIL. Supremo Tribunal Federal. Agravo Regimental no Recurso Extraordinário n. 271.286-8/RS. Relator Ministro Celso de Mello. Agravante: Município de Porto Alegre. Agravada: Diná Rosa Vieira. Brasília, DF. Julgado em 12.09.2000. Publicado em 24.1 1.2000. Disponível em: <http://redir.stf.jus.br/paginadorpub/paginador.jsp?docTP=AC\&docID=335538>. Acesso em: 18 out. 2013 ; BRASIL. Supremo Tribunal Federal. RE 273.834/RS. Relator Ministro Celso de Mello. Agravante: Município de Porto Alegre. Agravada: Laura Antunes de Matos. Brasília, DF. Julgado em 23.08.2000. Publicado em 18.09.2000. Disponível em: <http://stf.jus.br/portal/jurisprudencia/listarJurisprudencia.asp?s1=\%28RE\%24\%2ESCLA\%2E+E+273834\%2ENUME\%2E\%29 \&base=baseMonocraticas\&url=http://tinyurl.com/cp33gaa $>$. Acesso em: 18 out. 2013; BRASIL. Supremo Tribunal Federal. $R E$ 393.175-O/RS. Relator Ministro Celso de Mello. Agravante: Estado do Rio Grande do Sul. Agravados: Luiz Marcelo Dias e outros. Brasília, DF. Julgado em 12.12.2006. Publicado em 02.02.2007. Disponível em: $<$ http://redir.stf.jus.br/paginadorpub/paginador.jsp?docTP=AC\&docID=402582>. Acesso em: 16 out. 2013.

${ }^{19}$ No mesmo sentido: BRASIL. Supremo Tribunal Federal. RE 273.834/RS. Relator Ministro Celso de Mello. Agravante: Município de Porto Alegre. Agravada: Laura Antunes de Matos. Brasília, DF. Julgado em 23.08.2000. Publicado em 18.09.2000. Disponível

em: <http://stf.jus.br/portal/jurisprudencia/listarJurisprudencia.asp?s1=\%28RE\%24\%2ESCLA\%2E+E+273834\%2ENUME\%2E\%29 vol.09, nº. 01, Rio de Janeiro, 2016.pp. 56-83 
, externa o seu posicionamento, fruto de um duelo (ação e reação) de significados ocorrido previamente em sua mente, para, com o fito de combater posição contrária à sua, em seguida, energicamente, expor o seu posicionamento.

A postura emocional dos argumentos utilizados pelo Ministro Marco Aurélio na temática direito à saúde é identificada, entre outros, no julgamento do Recurso Extraordinário n. 368.564/DF, cuja relatoria inicial estava sob a relatoria do Ministro Menezes de Direito. No voto do referido RE, encontram-se argumentos no sentido de um sentimento puro, livre do choque proveniente do confronto da secundidade, nos moldes dos argumentos usados pelo Ministro Celso de Mello. Em outro sentido, posto que, em seus votos, depara-se com uma posição ideológica insuscetível de questionamento. Talvez verbalize dessa forma porque, em razão de sua posição ser tão firme, não vê necessidade de expor em seus votos o outro lado da moeda, mesmo que implicitamente. Para os argumentos do julgador, a questão é simples, pura. Há um sentimento muito definido com o fito de direcionar a sua racionalidade. Não sente a necessidade de fundamentar ou convencer os seus pares com argumentos refinados.

Essa atuação no plano da primeiridade não significa descompromisso com a concretude do direito à saúde, nem uma despreocupação com o resultado final dos julgamentos, mas o oposto disso. Na questão, cita-se o julgamento do recurso extraordinário mencionado linhas atrás, no qual o então relator votara para conhecer e prover o recurso. O julgamento caminhava para a decisão final, quando o Ministro Marco Aurélio se deu conta de que era possível que a decisão do tribunal a quo, na qual se determinou o pagamento de tratamento de doença ocular em Havana, poderia ainda não ter sido cumprida.

Em consequência desse cenário, eventual julgamento desfavorável naquele momento (08/04/2008) prejudicaria os cidadãos beneficiados pela decisão judicial recorrida. Não obstante já ter posição formada sobre o tema, o Ministro Marco Aurélio tomou uma decisão inusitada: pediu vista dos autos, em seguida fez um pedido de adiamento, o que retardou o julgamento final para 13/04/2011. O retardo do julgamento motivou o Ministro Ricardo Lewandowski a mencionar que já houvera o cumprimento da decisão, mas que, como se trata de um tema importante do aspecto teórico, o recurso deveria ser julgado. Durante os debates, entre muitos argumentos contrários, argumentou-se que a referida doença não tem cura, consoante se posicionou a comunidade médica brasileira. Seria mais um argumento a fim de suspender o seu adimplemento. Ao final, também em vão, porquanto por maioria, prevaleceu a tese do Ministro Marco Aurélio, que defende o pagamento pelo Estado de tratamentos de alto custo.

\&base=baseMonocraticas\&url=http://tinyurl.com/cp33gaa $>$. Acesso em: 16 out. 2013; BRASIL. Supremo Tribunal Federal. $R E$ 393.175-O/RS. Relator Ministro Celso de Mello. Agravante: Estado do Rio Grande do Sul. Agravados: Luiz Marcelo Dias e outros. Brasília, DF. Julgado em 12.12.2006. Publicado em 02.02.2007. Disponível em: $<$ http://redir.stf.jus.br/paginadorpub/paginador.jsp?docTP=AC\&docID=402582>. Acesso em: 16 out. 2013. 
Além, obviamente, da análise do contexto do julgamento, pode-se transcrever alguns trechos que, por si sós, ajudam a apreender a classificação da dialogia peirceana, no plano da primeiridade, a saber: "O SENHOR MINISTRO MARCO AURÉLIO (PRESIDENTE) - Estou desprovendo e mantendo o acórdão. O recurso é da União. Certamente, com esse tratamento, a viúva não ficará mais pobre! ” (BRASIL. Supremo Tribunal Federal. $R E$ n. 368.564/DF, j. 13.04.2011). A seguir, no mesmo julgado:

O SENHOR MINISTRO MARCO AURÉLIO (PRESIDENTE) - Essa denominada reserva do possível, no tocante ao Estado, leva-me à indignação como contribuinte, como cidadão, como juiz, pois, se for realmente empolgada e aceita, teremos desculpa para tudo, porquanto, desde que me conheço, o Estado, em que pese a grande carga tributária, luta contra escassez de receita, mas luta porque tem despesas excessivas, principalmente com a máquina administrativa e a dívida interna.

Sob o julgo de outro raciocínio teórico, as construções extraídas das relatorias do Ministro Gilmar Mendes denotam um foco à construção de um raciocínio lógico, mais refletido, livre, numa primeira leitura, de um atuar puro ou emotivo. Isto fica muito claro ao se acompanhar a evolução do seu posicionamento sobre a judicialização da saúde. Concluiu, no tema, que não se trata de judicializar as políticas públicas, mas sim de as efetivar, uma vez que já existem na maioria dos litígios; o que ocorre é, por outro lado, uma inefetividade delas.

Para chegar a essa perspectiva, no entanto, encontram-se em seus votos dois importantes paradigmas: um deles é a consistência teórica, no sentido de buscar aprofundar o debate nas teorias constitucionais sobre os direitos fundamentais. O outro é a audiência pública realizada, quando - após ouvir diversas acepções sobre a judicialização da saúde - se formou a convicção de que não se trata de intervenção do Poder Judiciário nas políticas públicas em saúde. Com efeito, o enfoque da atuação jurisdicional deveria ser em outro sentido. Explanase que as políticas públicas destinadas à saúde existem e em grande escala, o que ocorre é que muitas delas restam ineficazes. Nessas situações, porque provocado, o Estado-juiz buscaria torná-las eficaz por meio de decisões judiciais voltadas para determinar situações específicas como, por exemplo, o fornecimento de determinado remédio que atenderia uma peculiaridade do caso concreto não abrangida pela política pública em voga, muitas vezes pensada de forma genérica para abranger o maior número de indivíduos.

Prenhe das dificuldades da análise das atuações jurisdicionais e, talvez, por essa constatação, com muita cautela, procura-se enfileirar a referida classificação no contexto peirceano com as peculiaridades da formação acadêmico-profissional dos ministros, obviamente de período anterior ao respectivo ingresso ao Supremo Tribunal. Nesse cenário, pondera-se que há uma relação direta da formação acadêmico-profissional prévia com a sua atuação jurisdicional.

Dessa maneira, fulguram os argumentos usados pelo Ministro Celso de Mello com uma postura caracterizada na secundidade, quando em seu voto já se encontram a ação e a reação dos signos envolvidos, a 
resultar num interpretante emocional, apaixonado, tipicamente como um membro do Ministério Público, cuja postura se caracteriza pela litigiosidade em favor de um valor que considera maior e, por sua concretude, busca o seu predomínio acima de tudo. Literalmente, na leitura do signo emanado dos seus votos, extraem-se o signo e o objeto que ajudaram a forjá-lo como interpretante. Os próprios trechos citados anteriormente identificam isso.

Esse enlace comunicacional descrito por Peirce sob o julgo da secundidade, predominantemente não pode ser encontrado nos argumentos usados nas decisões do Ministro Marco Aurélio. Na verbalização de seus votos, não há exatamente um choque entre ação e reação a resultar num novo símbolo; ao menos isso não está exposto em seus votos. Neste cerne, comenta que o processo intelectual interno à mente do ministro em voga, não pode ser analisado. Logo, o que se observa é a linguagem posta nas decisões estudadas.

À luz desse material de pesquisa, opina-se que o fato de a profissão anterior do ministro ser ligada ao direito do trabalho influenciou demasiadamente a sua atuação sob o viés da primeiridade. Essencialmente, o referido ramo do direito é voltado a equilibrar uma situação desigual: patrão versus empregado. O reequilíbrio é o seu mister. Tradicionalmente, a justiça do trabalho possui uma postura protetiva ao trabalhador.

Como decorrência desse espírito de busca pela igualdade, mesmo que seja de forma involuntária, identifica-se nas decisões (em seus argumentos) uma postura de reequilíbrio da situação, todavia, de forma pura e direta, como se não houvesse uma posição contrária. O tema é muito bem resolvido na convicção íntima do estudado julgador. Na sua mente, não há litígio ideológico ou doutrinário. Há, ao inverso disso, um sentimento livre, ou seja, sem a materialização pela verbalização de uma posição contrária como parte do debate. Desta forma, julgou os Recursos Extraordinários n. 247.900/RS e n. 368.564/DF, bem como o Agravo Regimental no Agravo de Instrumento n. 238.328/RS.

No mesmo enredo de análise, os argumentos constantes nos votos do Ministro Gilmar acabam por identificar a sua elevada formação acadêmica, com destaque para a dimensão constitucional da sua pesquisa, a qual invariavelmente forneceu subsídio para a classificação da sua atuação na terceiridade. Em seus votos, o ministro procura construir um raciocínio científico ou ao menos dar maior consistência teórica, a fim de legitimar o julgamento final. Por assim dizer, nos argumentos constantes nos seus votos há um raciocínio mais elaborado; uma construção doutrinária para chegar à solução da lide.

De outro modo, é importante destacar que não se trata aqui de legitimar o uso da teoria desenvolvida pelo Ministro Gilmar Mendes ou mesmo fazer qualquer análise da compatibilidade ou não dos autores servidos pelo julgador. Não se passa nem perto disso. A abordagem é outra. Por aqui, identifica-se no seu discurso um afastamento de um sentimento puro (quase que idealista), de uma ação apaixonada (com fim delimitado), para com o cerne de tecer um arrazoado em busca de argumentação jurídica mais sólida, numa perspectiva mais lógica, a formar um plexo teórico que o direcionará sem ser guiado pela paixão. 


\title{
PRAGMATIC DESCRIPTION OF THE SUPREME FEDERAL COURT ACTING ON RIGHT TO HEALTH
}

\begin{abstract}
The research analyzes the jurisprudence of the Supreme Federal Court - STF on the right to health in order to describe the rationale of the Supreme Brazilian Court through the classification of the arguments used in the decisions analyzed according to pragmatic authored by philosopher linguist Charles Peirce. For the empirical study, through research methods, we used document research, collected from judicial precedents of the Supreme Court. The research results were mainly:

1. The proposed classification of the arguments used by the judgments in three groups: energetic interpretant, emotional interpretant and logic interpretant;

2. A new reading of the decision-making process in the Supreme Court.
\end{abstract}

Keywords: Right to health. Supreme Federal Court. Pragmatics. Arguments. Interpretant.

\section{REFERENCIAS}

ARAÚJO, Clarice von Oertzen de. Semiótica do direito. Quartier Latin: São Paulo, 2005. Incidência jurídica: teoria e crítica. Noeses: São Paulo, 2011.

BRASIL. Supremo Tribunal Federal. Agravo de Instrumento n. 238.328/RS. Relator Ministro Marco Aurélio. Requerente: Município de Porto Alegre. Requerido: Ana Luiza Soares de Carvalho. Brasília, DF. Julgado em 16.11.1999. Publicado em 18.02. /2000. Disponível em: <http://stf.jus.br/portal/jurisprudencia/listarJurisprudencia.asp?s1=\%28AI\%24\%2ESCLA\%2E+E+238328\%2E NUME\%2E\%29+OU+\%28AI\%2EACMS\%2E+ADJ2+238328\%2EACMS\%2E\%29\&base=baseAcordaos\&url= http://tinyurl.com/p39qk6b>. Acesso em: 16 out. 2013.

Supremo Tribunal Federal. Agravo Regimental no Recurso Extraordinário n. 271.286-8/RS. Relator Ministro Celso de Mello. Agravante: Município de Porto Alegre. Agravada: Diná Rosa Vieira. Brasília, DF. Julgado em 12.09.2000. Publicado em 24.11.2000. Disponível em: <http://redir.stf.jus.br/paginadorpub/paginador.jsp?docTP=AC\&docID=335538>. Acesso em: 18 out. 2013. Supremo Tribunal Federal. Pesquisa de Jurisprudência. Disponível em: <http://www.stf.jus.br/portal/jurisprudencia/pesquisarJurisprudencia.asp>. Acesso em: 24 out. 2013.

Supremo Tribunal Federal. Recurso Extraordinário n. 247.900/RS Relator Ministro Marco Aurélio. Requerente: Estado do Rio Grande do Sul. Requerida: Ida Maria Lopez Huber e outros. Brasília, DF. Julgado em 20.09.1999. Publicado em 27.10.1999. Disponível em: <http://stf.jus.br/portal/jurisprudencia/listarJurisprudencia.asp?s1=\%28RE\%24\%2ESCLA\%2E+E+247900\%2E NUME\%2E\%29\&base=baseMonocraticas\&url=http://tinyurl.com/oezb9ox >. Acesso em: 16 out. 2013.

Supremo Tribunal Federal. RE 273.834/RS. Relator Ministro Celso de Mello. Agravante: Município de Porto Alegre. Agravada: Laura Antunes de Matos. Brasília, DF. Julgado em 23.08.2000. Publicado em 18.09.2000. Disponível <http://stf.jus.br/portal/jurisprudencia/listarJurisprudencia.asp?s1=\%28RE\%24\%2ESCLA\%2E+E+273834\%2E NUME\%2E\%29\&base=baseMonocraticas\&url=http://tinyurl.com/cp33gaa $>$. Acesso em: 18 out. 2013.

Supremo Tribunal Federal. RE n. 368.564/DF. Relator Ministro Menezes Direito. Recorrente União. Recorrido Maria Euridice de Lima Casali Brasília, DF. Julgado em 13.04.2011. Publicado em 10.08.2011, p. 81. 
Disponível em: <http://redir.stf.jus.br/paginadorpub/paginador.jsp?docTP=AC\&docID=625531 >. Acesso em: 16 out. 2013.

Supremo Tribunal Federal. RE 393.175-O/ RS. Relator Ministro Celso de Mello. Agravante: Estado do Rio Grande do Sul. Agravados: Luiz Marcelo Dias e outros. Brasília, DF. Julgado em 12.12.2006. Publicado em 02.02.2007. Disponível em: <http://redir.stf.jus.br/paginadorpub/paginador.jsp?docTP=AC\&docID=402582>. Acesso em: 16 out. 2013.

CASTRO JR, Torquato da Silva. A pragmática das nulidades e a teoria dos atos jurídicos inexistentes. São Paulo: Noeses, 2009.

CRESWELL, John W. Projeto de pesquisa. Métodos qualitativo, quantitativo e misto. 3. ed. Porto Alegre: Artmed, 2010.

GURVITCH, Georges. Elementos de sociologia jurídica. Tradução Jose M. Cajica Jr. Mexico: Elysan, 1948.

NEVES, Marcelo da Costa Pinto. Entre Hidra e Hércules. Princípios e regras constitucionais como diferença paradoxal do sistema jurídico. São Paulo: Martins Fontes, 2013.

PEIRCE, Charles Sanders. Escritos coligados. Selecionados e traduzidos por Armando Mora D'Oliveira e Sérgio Pormerangblum. São Paulo: Abril Cultural, 1974.

Semiótica. 3. ed. Tradução José Teixeira Coelho Neto. São Paulo: Perspectiva, 1999.

PIGNATARI, Décio. Semiótica \& literatura. Cotia: Atêlie Editorial, 2004.

SANTAELLA, Lucia. A teoria geral dos signos. Semiose e autogeração. São Paulo: Ática, 1995.

A percepção: uma teoria semiótica. 2. ed. São Paulo: Experimento, 1998.

Semiótica aplicada. São Paulo: Pioneira Thomson Learning, 2002.

O que é semiótica. São Paulo: Brasiliense, 2006.

SILVEIRA, Lauro Frederico Barbosa da. A comunicação de um ponto de vista pragmaticista. Cognitio 2. São Paulo, Educ-Angra, v. 1, n. 1, 2001.

Curso de semiótica geral. São Paulo: Quartier Latin, 2007.

TREVES, Renato. Sociologia del diritto. Torino: Enaudi, 1996.

TURIN, Roti Nielba. Introdução ao estudo das linguagens. [Aulas]. São Paulo: Annablume, 2007.

\section{APÊNDICE A - PLANILHA DAS DECISÕES ANALISADAS}

\begin{tabular}{|c|c|c|c|}
\hline RELATOR & $\begin{array}{c}\text { DATADA } \\
\text { PUBLICAÇÃO }\end{array}$ & TÉCNICA PROCESSUAL & PARTES \\
\hline $\begin{array}{c}\text { Min. Antônio Cezar } \\
\text { Peluso }\end{array}$ & $11 / 2006$ & Ag. Reg. no AI n. 597.182 & $\begin{array}{c}\text { Agte: Estado do Rio Grande do } \\
\text { Sul } \\
\text { Agdo: Elvira Alves }\end{array}$ \\
\hline $\begin{array}{c}\text { Min. Antônio Cezar } \\
\text { Peluso }\end{array}$ & $09 / 2008$ & RE n. $584652 / \mathrm{RJ}$ & $\begin{array}{c}\text { Recte: A União } \\
\text { Rcdos: Produtos Veterinários }\end{array}$ \\
\hline
\end{tabular}




\begin{tabular}{|c|c|c|c|}
\hline & & & Manguinhos Ltda. \\
\hline $\begin{array}{l}\text { Min. Antônio Cezar } \\
\text { Peluso }\end{array}$ & $02 / 2010$ & REn. 523756ED. & $\begin{array}{c}\text { Embte: Estado do Espírito } \\
\text { Santo } \\
\text { Embdo: J.T.D.O. }\end{array}$ \\
\hline $\begin{array}{l}\text { Min. Antônio Cezar } \\
\text { Peluso }\end{array}$ & $05 / 2011$ & $\begin{array}{l}\text { Suspensão de Segurança n. } \\
\text { 4304/CE }\end{array}$ & $\begin{array}{l}\text { Rcdos: Relator do MS } \\
\text { Recte: Estado do Ceará }\end{array}$ \\
\hline $\begin{array}{l}\text { Min. Carlos Augusto } \\
\text { Ayres de Freitas Britto }\end{array}$ & $04 / 2011$ & ACn. $2836 \mathrm{MC} / \mathrm{SP}$ & $\begin{array}{l}\text { Reqte: Ministério Público do } \\
\text { Estado de São Paulo } \\
\text { Reqdo: Fazenda Pública do } \\
\text { Estado de São Paulo }\end{array}$ \\
\hline $\begin{array}{l}\text { Min. Carlos Augusto } \\
\text { Ayres de Freitas Britto }\end{array}$ & $02 / 2010$ & AIn. 611559/RS & $\begin{array}{l}\text { Recte: Conselho Regional de } \\
\text { Medicina do Estado do Rio } \\
\text { Grande do Sul } \\
\text { Recdo: União } \\
\text { Recdo: Município de Serafina } \\
\text { Corrêa }\end{array}$ \\
\hline $\begin{array}{l}\text { Min. Carlos Mario da } \\
\text { Silva Velloso }\end{array}$ & $09 / 2001$ & $\begin{array}{c}\text { Ag. Reg. no RE n. 273.042- } \\
\text { 4/RS }\end{array}$ & $\begin{array}{c}\text { Agte: Município de Porto } \\
\text { Alegre } \\
\text { Agdo: Carlos Alfredo de Souza } \\
\text { Luize }\end{array}$ \\
\hline $\begin{array}{l}\text { Min. Carlos Mario da } \\
\text { Silva Velloso }\end{array}$ & $03 / 2002$ & $\begin{array}{l}\text { EDCL no Ag. Reg. no RE n. } \\
273.042-4 / \text { RS }\end{array}$ & $\begin{array}{l}\text { Embte: Município de Porto } \\
\text { Alegre } \\
\text { Embdo: Carlos Alfredo de } \\
\text { Souza Luize }\end{array}$ \\
\hline $\begin{array}{l}\text { Min. Cármen Lúcia } \\
\text { Antunes Rocha }\end{array}$ & 2011 & $\begin{array}{l}\text { Ag. Reg. em Re. n. } \\
\text { 599529/RGS }\end{array}$ & $\begin{array}{l}\text { Agte: Estado do Rio Grande do } \\
\text { Sul } \\
\text { Agdo: Ministério Público do } \\
\text { Estado do Rio Grande do Sul }\end{array}$ \\
\hline $\begin{array}{l}\text { Min. Cármen Lúcia } \\
\text { Antunes Rocha }\end{array}$ & $02 / 2011$ & RE. n. 586995/MG & $\begin{array}{l}\text { Recte: Estado de Minas Gerais } \\
\text { Recido: Ministério Público do } \\
\text { Estado de Minas Gerais }\end{array}$ \\
\hline $\begin{array}{l}\text { Min. Cármen Lúcia } \\
\text { Antunes Rocha }\end{array}$ & $06 / 2011$ & Ag. no RE 599.529/RGS & $\begin{array}{c}\text { Agte: União } \\
\text { Agdo: Ministério Público } \\
\text { Federal }\end{array}$ \\
\hline $\begin{array}{l}\text { Min. Cármen Lúcia } \\
\text { Antunes Rocha }\end{array}$ & $05 / 2011$ & RE n. 607.385/SC & $\begin{array}{l}\text { Recte: Estado de Santa Catarina } \\
\text { Recido: Elisa Meira Fernandes }\end{array}$ \\
\hline $\begin{array}{l}\text { Min. Cármen Lúcia } \\
\text { Antunes Rocha }\end{array}$ & $08 / 2011$ & AG. em RE 646.235/SP & $\begin{array}{l}\text { Recte: Município de São Paulo } \\
\text { Recido: Ministério Público do } \\
\text { Estado de São Paulo }\end{array}$ \\
\hline $\begin{array}{l}\text { Min. Cármen Lúcia } \\
\text { Antunes Rocha }\end{array}$ & $06 / 2011$ & RE n. 641916/PR & $\begin{array}{c}\text { Recte: Valentina Mikulski } \\
\text { Babinski } \\
\text { Rcdos: União, Estado do Paraná } \\
\text { e Município de Curitiba }\end{array}$ \\
\hline $\begin{array}{l}\text { Min. Cármen Lúcia } \\
\text { Antunes Rocha }\end{array}$ & $04 / 2011$ & $\begin{array}{l}\text { Ag. Reg. na Ação Cautelar } \\
\text { 2267/PR }\end{array}$ & $\begin{array}{c}\text { Agte: Valentina Mikulski } \\
\text { Babinski }\end{array}$ \\
\hline
\end{tabular}




\begin{tabular}{|c|c|c|c|}
\hline & & & $\begin{array}{c}\text { Agdo: União, Estado do Paraná, } \\
\text { Município de Curitiba }\end{array}$ \\
\hline $\begin{array}{l}\text { Min. Cármen Lúcia } \\
\text { Antunes Rocha }\end{array}$ & $03 / 2011$ & Ag. In. 823184/RS & $\begin{array}{l}\text { Agte: Estado do Rio Grande do } \\
\text { Sul } \\
\text { Agdo: Aguineu Diple Feline } \\
\text { Guellen } \\
\text { Intdo: Município de Soledade }\end{array}$ \\
\hline $\begin{array}{l}\text { Min. Cármen Lúcia } \\
\text { Antunes Rocha }\end{array}$ & $03 / 2012$ & $\begin{array}{l}\text { Ag. Reg. em Re. n. } \\
\text { 665.764/RGS }\end{array}$ & $\begin{array}{c}\text { Agte: União } \\
\text { Agdo: Associação de Caridade } \\
\text { Santa Casa do Rio Grande }\end{array}$ \\
\hline $\begin{array}{l}\text { Min. Cármen Lúcia } \\
\text { Antunes Rocha }\end{array}$ & $02 / 2012$ & Ag.Reg.no RE 648.410/DF & $\begin{array}{l}\text { Agte: Estado do Rio Grande do } \\
\text { Sul } \\
\text { Agdo: Ministério Público do } \\
\text { Estado do Rio Grande do Sul }\end{array}$ \\
\hline Min. Ellen Gracie & $10 / 2001$ & REn. 255.086-8/RS & $\begin{array}{l}\text { Reqte: Estado do Rio Grande } \\
\text { do Sul } \\
\text { Reqdo: Eduardo Leão Francisco } \\
\text { Marques }\end{array}$ \\
\hline Min. Ellen Gracie & $02 / 2007$ & STAn. 91 & $\begin{array}{l}\text { Reqte: Estado de Alagoas } \\
\text { Reqdo: Presidente do Tribunal } \\
\text { de Justiça do Estado de Alagoas }\end{array}$ \\
\hline Min. Ellen Gracie & $02 / 2007$ & SS n. 3073/RN & $\begin{array}{c}\text { Reqte: Estado do Rio Grande } \\
\text { do Sul } \\
\text { Reqdos: Luiz Carlos Fernandes } \\
\text { e } \\
\text { Relatora do Mandado de } \\
\text { Segurança }\end{array}$ \\
\hline Min. Ellen Gracie & $08 / 2010$ & $\begin{array}{l}\text { Ag. Reg. no Ag. Instrumento } \\
\text { de n. } 734.487 / \mathrm{PR}\end{array}$ & $\begin{array}{l}\text { Agte: Estado do Paraná } \\
\text { Agto: Ministério Público do } \\
\text { Estado do Paraná }\end{array}$ \\
\hline $\begin{array}{l}\text { Min. Enrique Ricardo } \\
\text { Lewandowski }\end{array}$ & $10 / 2006$ & AIn. 607.646/SC & $\begin{array}{c}\text { Agte: União } \\
\text { Agdo: Francisco Marini }\end{array}$ \\
\hline $\begin{array}{l}\text { Min. Enrique Ricardo } \\
\text { Lewandowski }\end{array}$ & $06 / 2009$ & Ag.Reg. no AI n. 553.712-4 & $\begin{array}{l}\text { Agte: Estado do Rio Grande do } \\
\text { Sul } \\
\text { Agdo: Neiva Cecilia Belle }\end{array}$ \\
\hline $\begin{array}{l}\text { Min. Enrique Ricardo } \\
\text { Lewandowski }\end{array}$ & $05 / 2011$ & Ag. no RE $640.722 / S C$ & $\begin{array}{c}\text { Recte: União } \\
\text { Recdo: Ministério Público } \\
\text { Federal }\end{array}$ \\
\hline $\begin{array}{l}\text { Min. Enrique Ricardo } \\
\text { Lewandowski }\end{array}$ & $08 / 2011$ & RE n. 628.293/AM & $\begin{array}{l}\text { Recte: Estado do Amazonas } \\
\text { Recdo: Ministério Público do } \\
\text { Estado do Amazonas }\end{array}$ \\
\hline $\begin{array}{c}\text { Min. Gilmar Ferreira } \\
\text { Mendes }\end{array}$ & $03 / 2010$ & $\begin{array}{l}\text { Ag. Reg. na Suspensão da } \\
\text { Segurança n. 3355 RN }\end{array}$ & $\begin{array}{l}\text { Agte: Estado do Rio Grande do } \\
\text { Norte } \\
\text { Agdo: Grinaldo Ferreira da Silva }\end{array}$ \\
\hline
\end{tabular}




\begin{tabular}{|c|c|c|c|}
\hline $\begin{array}{c}\text { Min. Gilmar Ferreira } \\
\text { Mendes }\end{array}$ & $04 / 2010$ & $\begin{array}{l}\text { Ag. Reg. na Suspensão de } \\
\text { Liminar n. } 47 \text { Pernambuco }\end{array}$ & $\begin{array}{l}\text { Agte: Estado de Pernambuco } \\
\text { Agdo: União } \\
\text { Agdo: Ministério Público } \\
\text { Federal } \\
\text { Agdo: Município de Petrolina }\end{array}$ \\
\hline $\begin{array}{l}\text { Min. Gilmar Ferreira } \\
\text { Mendes }\end{array}$ & $04 / 2010$ & $\begin{array}{l}\text { Ag. Reg. na Suspensão de } \\
\text { Tutela Antecipada n. } 175 \\
\text { Ceará }\end{array}$ & $\begin{array}{c}\text { Agte: União } \\
\text { Agdo: Clarice de Abreu de } \\
\text { Castro Neves } \\
\text { Agdo: Ministério Público } \\
\text { Federal } \\
\text { Agdo: Município de Fortaleza } \\
\text { Agdo: Estado do Ceará }\end{array}$ \\
\hline $\begin{array}{l}\text { Min. Gilmar Ferreira } \\
\text { Mendes }\end{array}$ & $04 / 2010$ & STA n. 278 & $\begin{array}{l}\text { Agte: Estado de Alagoas } \\
\text { Agdo: Maria de Lourdes da } \\
\text { Silva }\end{array}$ \\
\hline $\begin{array}{l}\text { Min. Gilmar Ferreira } \\
\text { Mendes }\end{array}$ & $04 / 2010$ & $\begin{array}{l}\text { Ag. Reg. na Suspensão de } \\
\text { Segurança n. } 2361\end{array}$ & $\begin{array}{c}\text { Agte: Estado de Pernambuco } \\
\text { Agdo: Alessandro Feitosa Tomé } \\
\text { de Souza }\end{array}$ \\
\hline $\begin{array}{l}\text { Min. Gilmar Ferreira } \\
\text { Mendes }\end{array}$ & $04 / 2010$ & $\begin{array}{l}\text { Ag. Reg. na Suspensão de } \\
\text { Segurança n. } 2944\end{array}$ & $\begin{array}{c}\text { Agte: Estado da Paraíba } \\
\text { Imptes: Zilda Miranda Torres } \\
\text { Joelma dos Santos Nascimento } \\
\text { Antônio Francisco da Cruz } \\
\text { Filho } \\
\text { Maria Pereira da Cunha }\end{array}$ \\
\hline $\begin{array}{l}\text { Min. Joaquim } \\
\text { Benedito Barbosa } \\
\text { Gomes }\end{array}$ & $08 / 2006$ & AIn. 507.072/MG & $\begin{array}{l}\text { Agte: Estado de Minas Gerais } \\
\text { Agdo: José Carraro }\end{array}$ \\
\hline $\begin{array}{l}\text { Min. Joaquim } \\
\text { Benedito Barbosa } \\
\text { Gomes }\end{array}$ & $04 / 2011$ & Ag. Reg. no RE 635381/RS & $\begin{array}{l}\text { Recte: Estado do Rio Grande do } \\
\text { Sul } \\
\text { Recdo: Valzumiro Zanatta }\end{array}$ \\
\hline $\begin{array}{l}\text { Min. Joaquim } \\
\text { Benedito Barbosa } \\
\text { Gomes }\end{array}$ & $10 / 2011$ & $\begin{array}{l}\text { Ag. Reg. no AI } \\
\text { 693.564/RGS }\end{array}$ & $\begin{array}{c}\text { Agte: Município de Porto } \\
\text { Alegre } \\
\text { Agdo: Cristian da Costa Nery }\end{array}$ \\
\hline $\begin{array}{l}\text { Min. Joaquim } \\
\text { Benedito Barbosa } \\
\text { Gomes }\end{array}$ & $10 / 2011$ & Ag. Reg. no AI 817241/RGS & $\begin{array}{c}\text { Agte: Estado do Rio Grande do } \\
\text { Sul } \\
\text { Agdo: Branca Odete Mendes } \\
\text { Acosta }\end{array}$ \\
\hline $\begin{array}{l}\text { Min. Joaquim } \\
\text { Benedito Barbosa } \\
\text { Gomes }\end{array}$ & $06 / 2012$ & $\begin{array}{l}\text { Ag. Reg. no AI n. } \\
\text { 550.530/PR }\end{array}$ & $\begin{array}{l}\text { Agte: Autarquia Municipal de } \\
\text { Saúde } \\
\text { Agto: Ministério Público do } \\
\text { Estado do Paraná }\end{array}$ \\
\hline $\begin{array}{l}\text { Min. José Antônio } \\
\text { Dias Toffoli }\end{array}$ & $02 / 2010$ & AI n. 587084/PR & $\begin{array}{l}\text { Recte: Andréia Pichorim } \\
\text { Recdo: União }\end{array}$ \\
\hline $\begin{array}{l}\text { Min. José Antônio } \\
\text { Dias Toffoli }\end{array}$ & $06 / 2010$ & AIn. 667882/MG & $\begin{array}{l}\text { Agte: Ministério Público do } \\
\text { Estado de Minas Gerais } \\
\text { Agdo: Município de Contagem }\end{array}$ \\
\hline
\end{tabular}




\begin{tabular}{|c|c|c|c|}
\hline Min. Ilmar Galvão & 09/1999 & RE n. 242.859-RS & $\begin{array}{c}\text { Agte: Município de Porto } \\
\text { Alegre } \\
\text { Agdo: Patrícia Palácio de Souza }\end{array}$ \\
\hline Min. Ilmar Galvão & $03 / 2000$ & RE n. 226.835-6/RS & $\begin{array}{l}\text { Recte: Estado do Rio Grande do } \\
\text { Sul } \\
\text { Recdo: Rosemari Pereira dias }\end{array}$ \\
\hline $\begin{array}{l}\text { Min. José Carlos } \\
\text { Moreira Alves }\end{array}$ & $05 / 2000$ & RE n. 264.269/RS & $\begin{array}{l}\text { Recte: Estado do Rio Grande do } \\
\text { Sul } \\
\text { Recda: Teresinha Palhano }\end{array}$ \\
\hline $\begin{array}{l}\text { Min. José Carlos } \\
\text { Moreira Alves }\end{array}$ & $09 / 2000$ & RE n. 207.970-7/RS & $\begin{array}{c}\text { Recte: Estado do Rio Grande do } \\
\text { Sul } \\
\text { Recdo: Osvaldina Alves dos } \\
\text { Passos }\end{array}$ \\
\hline $\begin{array}{l}\text { Min. José Celso de } \\
\text { Mello Filho }\end{array}$ & $02 / 1997$ & Pet.n.1.246 MC/SC & $\begin{array}{l}\text { Reqte: Estado de Santa Catarina } \\
\text { Recdo: João Batista Gonçalves } \\
\text { Cordeiro }\end{array}$ \\
\hline $\begin{array}{l}\text { Min. José Celso de } \\
\text { Mello Filho }\end{array}$ & $08 / 2000$ & RE n. 267.612-RS & $\begin{array}{l}\text { Reqte: Estado do Rio Grande } \\
\text { do Sul } \\
\text { Reqdo: Augusto Seleprioni }\end{array}$ \\
\hline $\begin{array}{l}\text { Min. José Celso de } \\
\text { Mello Filho }\end{array}$ & $08 / 2000$ & RE n. 232.335/RS & $\begin{array}{l}\text { Reqte: Estado do Rio Grande } \\
\quad \text { do Sul } \\
\text { Reqdo: Jorge Eduardo Hennig }\end{array}$ \\
\hline $\begin{array}{l}\text { Min. José Celso de } \\
\text { Mello Filho }\end{array}$ & $11 / 2000$ & $\begin{array}{c}\text { Ag. Reg. em Re. n. 271.286- } \\
\text { 8/ RS }\end{array}$ & $\begin{array}{c}\text { Agda: Cândida Silveira Saibert } \\
\text { Agda: Dina Rosa Vieira } \\
\text { Agte: Município de Porto } \\
\text { Alegre }\end{array}$ \\
\hline $\begin{array}{l}\text { Min. José Celso de } \\
\text { Mello Filho }\end{array}$ & $02 / 2001$ & $\begin{array}{c}\text { Ag.Reg. em RE. n. } \\
\text { 273.834/RS }\end{array}$ & $\begin{array}{l}\text { Agde: Município de Porto } \\
\text { Alegre } \\
\text { Agvda: Cristiane Carneiro } \\
\text { Bortolaz }\end{array}$ \\
\hline $\begin{array}{l}\text { Min. José Celso de } \\
\text { Mello Filho }\end{array}$ & $12 / 2001$ & RE n. 248.304/RS & $\begin{array}{l}\text { Recte: Estado do Rio Grande do } \\
\text { Sul } \\
\text { Recdo: Igor Batista Brito }\end{array}$ \\
\hline $\begin{array}{l}\text { Min. José Celso de } \\
\text { Mello Filho }\end{array}$ & $04 / 2004$ & ADPF n. 45/DF & $\begin{array}{c}\text { Reqte: Partido da Social } \\
\text { Democracia Brasileira - PSDB } \\
\text { Reqdo: Presidente da República }\end{array}$ \\
\hline
\end{tabular}




\begin{tabular}{|c|c|c|c|}
\hline $\begin{array}{l}\text { Min. José Celso de } \\
\text { Mello Filho }\end{array}$ & $06 / 2004$ & AIn. 452.312/RS & $\begin{array}{l}\text { Agte: Município de Porto } \\
\quad \text { Alegre } \\
\text { Agdo: Camila Kauffmann }\end{array}$ \\
\hline $\begin{array}{l}\text { Min. José Celso de } \\
\text { Mello Filho }\end{array}$ & $02 / 2007$ & $\begin{array}{c}\text { Ag. Reg. em Ren. } 393.175- \\
\text { O - RS }\end{array}$ & $\begin{array}{c}\text { Agte: Estado do Rio Grande do } \\
\text { Sul } \\
\text { Agda: Luiz Marcelo Dias e } \\
\text { outro (A/S) }\end{array}$ \\
\hline $\begin{array}{l}\text { Min. José Paulo } \\
\text { Sepúlveda Pertence }\end{array}$ & $12 / 2005$ & AI n. 562.561/RS & $\begin{array}{l}\text { Agte: Estado do Rio Grande do } \\
\text { Sul } \\
\text { Agda: João Abrantes Mendonça }\end{array}$ \\
\hline Min. Luiz Fux & $04 / 2011$ & $\begin{array}{l}\text { Ag. REg. no RE } \\
626.328 / \text { RGS }\end{array}$ & $\begin{array}{l}\text { Agte: Estado do Rio Grande do } \\
\text { Sul } \\
\text { Agto: Luis Felipe Alves Varante }\end{array}$ \\
\hline Min. Luiz Fux & $06 / 2011$ & $\begin{array}{l}\text { Ag. Reg. no RE } \\
626.328\end{array}$ & $\begin{array}{l}\text { Agte: Estado do Paraná } \\
\text { Agdo: Ministério Público do } \\
\text { Estado do Paraná }\end{array}$ \\
\hline Min. Luiz Fux & $06 / 2011$ & Ag. Reg. no Re. 607.381/SC & $\begin{array}{l}\text { Agte: Estado de Santa Catarina } \\
\text { Agdo: Ruth Maria Rosa }\end{array}$ \\
\hline Min. Luiz Fux & $08 / 2011$ & Ag. In. n. 843160/MG & $\begin{array}{l}\text { Agte: Ministério Público do } \\
\text { Estado de Minas Gerais } \\
\text { Agdo: Departamento Municipal } \\
\text { de Saúde Pública - DEMASP }\end{array}$ \\
\hline Min. Luiz Fux & $04 / 2012$ & $\begin{array}{l}\text { Ag. REg. no RE n. } \\
\text { 668.724/RS }\end{array}$ & $\begin{array}{l}\text { Agte: Estado do Rio Grande do } \\
\text { Sul } \\
\text { Agdo: Germana Pereira Ferreira }\end{array}$ \\
\hline $\begin{array}{l}\text { Min. Marco Aurélio } \\
\text { Mendes de Farias } \\
\text { Mello }\end{array}$ & 02/1999 & AI n. 232.469/RS & $\begin{array}{c}\text { Agte: Município de Porto } \\
\text { Alegre } \\
\text { Agda: Loreni de Fátima Santos } \\
\text { Serpa }\end{array}$ \\
\hline $\begin{array}{l}\text { Min. Marco Aurélio } \\
\text { Mendes de Farias } \\
\text { Mello }\end{array}$ & $10 / 1999$ & RE n. 247.900-RS & $\begin{array}{l}\text { Reqte: Estado do Rio Grande } \\
\text { do Sul } \\
\text { Reqda: Ida Maria Lorez Huber }\end{array}$ \\
\hline $\begin{array}{l}\text { Min. Marco Aurélio } \\
\text { Mendes de Farias } \\
\text { Mello }\end{array}$ & $02 / 2000$ & $\begin{array}{l}\text { Ag.Reg. em Agravo de } \\
\text { Instrumento n. 238.328-RS }\end{array}$ & $\begin{array}{c}\text { Agte: Município de Porto } \\
\text { Alegre } \\
\text { Agda: Carlos Fernando Becker }\end{array}$ \\
\hline $\begin{array}{l}\text { Min. Marco Aurélio } \\
\text { Mendes de Farias } \\
\text { Mello }\end{array}$ & $03 / 2000$ & RE n. 195.192-3-RS & $\begin{array}{l}\text { Recte: Estado do Rio Grande do } \\
\text { Sul } \\
\text { Recdo: Rodrigo Skrsypcsak }\end{array}$ \\
\hline $\begin{array}{l}\text { Min. Marco Aurélio } \\
\text { Mendes de Farias } \\
\text { Mello }\end{array}$ & $09 / 2000$ & RE n. 273.042-RS & $\begin{array}{c}\text { Rectes: Estado do Rio Grande } \\
\text { do Sul e Município de Porto } \\
\text { Alegre } \\
\text { Recdo: Carlos Alfredo de Souza }\end{array}$ \\
\hline
\end{tabular}




\begin{tabular}{|c|c|c|c|}
\hline & & & Luize \\
\hline $\begin{array}{l}\text { Min. Marco Aurélio } \\
\text { Mendes de Farias } \\
\text { Mello }\end{array}$ & $12 / 2007$ & RE n. 566.471 RG/RN & $\begin{array}{l}\text { Recte: Estado do Rio Grande do } \\
\text { Norte } \\
\text { Recda: Carmelita Anunciada de } \\
\text { Souza }\end{array}$ \\
\hline $\begin{array}{l}\text { Min. Marco Aurélio } \\
\text { Mendes de Farias } \\
\text { Mello }\end{array}$ & $08 / 2011$ & REn. 368.564/DF & $\begin{array}{c}\text { Recte: União } \\
\text { Recdo: Maria Euridice de Lima } \\
\text { Casale }\end{array}$ \\
\hline $\begin{array}{l}\text { Min. Marco Aurélio } \\
\text { Mendes de Farias } \\
\text { Mello }\end{array}$ & $03 / 2012$ & REn. 657.718 RG/MG & $\begin{array}{l}\text { Reqte: Alcirene de Oliveira } \\
\text { Reqdo: Estado de Minas Gerais }\end{array}$ \\
\hline $\begin{array}{l}\text { Min. Marco Aurélio } \\
\text { Mendes de Farias } \\
\text { Mello }\end{array}$ & $05 / 2012$ & $\begin{array}{l}\text { Ag. Reg. no RE n. } \\
\text { 635.363/RS }\end{array}$ & $\begin{array}{l}\text { Agte: Município de Caxias do } \\
\text { Sul } \\
\text { Agdo: Ministério Público do } \\
\text { Estado do Rio Grande do Sul }\end{array}$ \\
\hline $\begin{array}{l}\text { Min. Maurício José } \\
\text { Corrêa }\end{array}$ & $08 / 1999$ & RE n. 236.000/RS & $\begin{array}{l}\text { Reqte: Estado do Rio Grande } \\
\text { do Sul } \\
\text { Reqdos: Alex Lopez de Souza e } \\
\text { outros }\end{array}$ \\
\hline $\begin{array}{l}\text { Min. Maurício José } \\
\text { Corrêa }\end{array}$ & 09/1999 & RE n. 236.644/RS & $\begin{array}{c}\text { Reqte: Município de Porto } \\
\text { Alegre } \\
\text { Reqdo: Carlos Alberto Ebeling } \\
\text { Duarte }\end{array}$ \\
\hline $\begin{array}{l}\text { Min. Maurício José } \\
\text { Corrêa }\end{array}$ & $08 / 2000$ & $\begin{array}{l}\text { Ag. Reg. no RE n. } \\
\text { 259.508/RS }\end{array}$ & $\begin{array}{c}\text { Agte: Município de Porto } \\
\text { Alegre } \\
\text { Agdo: Patrício Palácio de Souza }\end{array}$ \\
\hline Min. Nelson Jobim & $02 / 2001$ & AgRg. no RE n. 255.627-RS & $\begin{array}{c}\text { Agte: Município de Porto } \\
\text { Alegre } \\
\text { Agdo: Carlos Alberto Ebeling } \\
\text { Duarte }\end{array}$ \\
\hline
\end{tabular}

Fonte: Pesquisa de Jurisprudência (BRASIL, 2015).

Trabalho enviado em 29 de julho de 2015.

Aceito em 01 de outubro de 2015. 